\title{
Sphingosine kinase 2 restricts T cell immunopathology but permits viral persistence
}

\author{
Caleb J. Studstill, ${ }^{1}$ Curtis J. Pritzl, ${ }^{1}$ Young-Jin Seo, ${ }^{2}$ Dae Young Kim, ${ }^{3}$ Chuan Xia, ${ }^{1}$ Jennifer J. Wolf, ${ }^{1}$ Ravi Nistala, ${ }^{4}$ \\ Madhuvanthi Vijayan, ${ }^{1}$ Yong-Bin Cho, ${ }^{2}$ Kyung Won Kang, ${ }^{5}$ Sang-Myeong Lee, ${ }^{5,6}$ and Bumsuk Hahm ${ }^{1}$ \\ 'Departments of Surgery and Molecular Microbiology and Immunology, University of Missouri-Columbia, Columbia, Missouri, USA. Department of Life Science, Chung-Ang University, Seoul, Korea. \\ ${ }^{3}$ Veterinary Medical Diagnostic Laboratory, College of Veterinary Medicine, ${ }^{4}$ Division of Nephrology, Department of Medicine, University of Missouri-Columbia, Columbia, Missouri, USA. ${ }^{5}$ Division of \\ Biotechnology, College of Environmental and Bioresource Sciences, Jeonbuk National University, Iksan, Korea. ${ }^{6}$ College of Veterinary Medicine, Chungbuk National University, Cheongju, Korea.
}

\begin{abstract}
Chronic viral infections are often established by the exploitation of immune-regulatory mechanisms that result in nonfunctional T cell responses. Viruses that establish persistent infections remain a serious threat to human health. Sphingosine kinase 2 (SphK2) generates sphingosine 1-phosphate, which is a molecule known to regulate multiple cellular processes. However, little is known about SphK2's role during the host immune responses to viral infection. Here, we demonstrate that SphK2 functions during lymphocytic choriomeningitis virus $\mathrm{Cl} 13$ (LCMV Cl 13) infection to limit T cell immune pathology, which subsequently aids in the establishment of virus-induced immunosuppression and the resultant viral persistence. The infection of Sphk2-deficient (Sphk2-/-) mice with LCMV Cl 13 led to the development of nephropathy and mortality via T cell-mediated immunopathology. Following LCMV infection, Sphk2-/- CD4 ${ }^{+} \mathrm{T}$ cells displayed increased activity and proliferation, and these cells promoted overactive LCMV CI 13-specific CD8 ${ }^{+}$T cell responses. Notably, oral instillation of an SphK2-selective inhibitor promoted protective T cell responses and accelerated the termination of LCMV CI 13 persistence in mice. Thus, SphK2 is indicated as an immunotherapeutic target for the control of persistent viral infections.
\end{abstract}

\section{Introduction}

Viruses such as HIV, hepatitis B virus (HBV), and hepatitis C virus (HCV) often evade or impair host antiviral immunity to establish chronic infections $(1,2)$. Particularly, the loss of both $\mathrm{CD}^{+}$and $\mathrm{CD}^{+} \mathrm{T}$ cell functionalities, including $\mathrm{T}$ cell proliferation and antiviral cytokine production, is observed during persistent viral infections (3-5). The infection of mice with lymphocytic choriomeningitis virus (LCMV) is a useful model for the mechanistic study of viral immune regulation as well as for the identification of cellular targets that are critical for viral persistence in humans. LCMV infection is generally symptomless in immunocompetent humans, but life-threatening to patients undergoing organ transplantation $(6,7)$. Infection of mice with the prototypic strain of LCMV, Armstrong 53b (Arm), induces a rigorous $\mathrm{CD}^{+} \mathrm{T}$ cell response that rapidly eradicates the virus from its host. In contrast, the clone 13 (Cl13) strain of LCMV intensely suppresses the host's immune system, leading to viral persistence lasting over 60 days after infection (8-10). LCMV Cl 13 retains the same T cell epitopes as Arm, but it induces $\mathrm{T}$ cell dysfunction. Therefore, the concept of $\mathrm{T}$ cell exhaustion was established in this animal model system $(5,11)$. Several $\mathrm{T}$ cell inhibitory molecules were proven to be important for the generation of exhausted $\mathrm{CD} 8^{+} \mathrm{T}$ cells contributing to viral immune regulation and viral persistence $(4,12-19)$. Also, CD $4^{+}$

Authorship note: CJS, CJP, and YJS contributed equally to this work. Conflict of interest: The authors have declared that no conflict of interest exists. Copyright: @ 2020, American Society for Clinical Investigation.

Submitted: October 4, 2018; Accepted: September 2, 2020; Published: November 9, 2020. Reference information: J Clin Invest. 2020;130(12):6523-6538.

https://doi.org/10.1172/JCI125297.
$\mathrm{T}$ cell help is critical for maintaining the functionality of virusspecific $\mathrm{CD}^{+} \mathrm{T}$ cells during a persistent viral infection. Elimination of $\mathrm{CD}^{+} \mathrm{T}$ cells leads to an increase in the number of exhausted $\mathrm{CD}^{+} \mathrm{T}$ cells, which results in impaired control of LCMV Cl 13 infection $(5,20,21)$. Loss of $\mathrm{CD}^{+} \mathrm{T}$ cell responses was also shown to be associated with the exhausted $\mathrm{CD}^{+} \mathrm{T}$ cell phenotype during HIV and HCV infections $(22,23)$. Nevertheless, the detailed mechanism by which viruses control host $\mathrm{T}$ cell immunity to sustain viral persistence is incompletely understood.

Sphingolipids are bioactive lipid molecules that are composed of a serine head group with 1 or 2 fatty acid tails. Sphingosine 1-phosphate (S1P) is one of several sphingolipid metabolites that is known to be important for versatile cellular processes and diseases, including cell survival, cellular differentiation, cell trafficking, tumor progression, and the host immune system (24-26). S1P is generated from sphingosine by sphingosine kinase (SphK). The 2 isoforms of SphK, SphK1 and SphK2, share the same enzymatic function to generate bioactive S1P. However, these enzymes are encoded by 2 different genes, have distinct subcellular localizations, and appear to exhibit differential biological activities, including immune modulation (27-32). SphK1, which mainly localizes to the plasma membrane and cytosol, is known to play a key role in the replication process of viruses, including influenza virus $(33,34)$, measles virus (35), and human CMV (hCMV) (36). SphK2, which localizes to the nucleus and cytoplasm, depending on cellular conditions, was reported to regulate cellular gene expression during chikungunya virus (CHIKV) infection, and maintain viral latency for Kaposi's sarcoma-associated herpesvirus (KHSV) (37, 38). Furthermore, we recently showed that transient inhibition of SphK1 or SphK2 promotes the control of influenza A virus (IAV) 
A

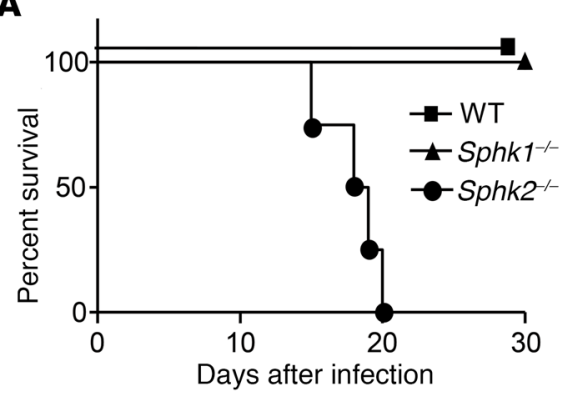

B

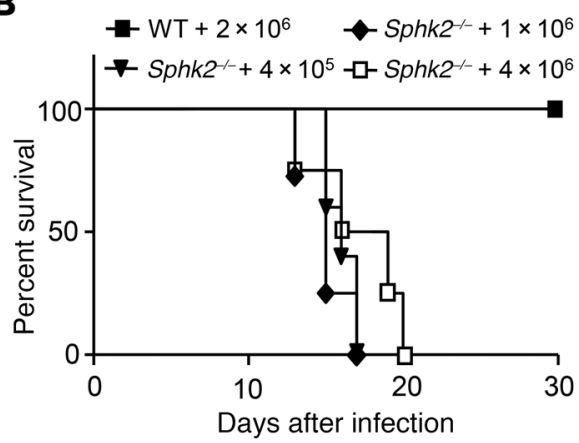

C

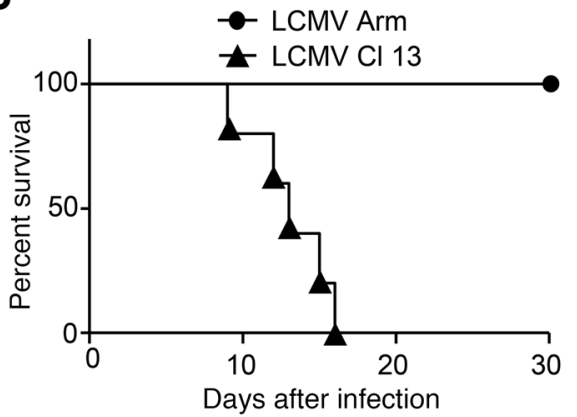

D

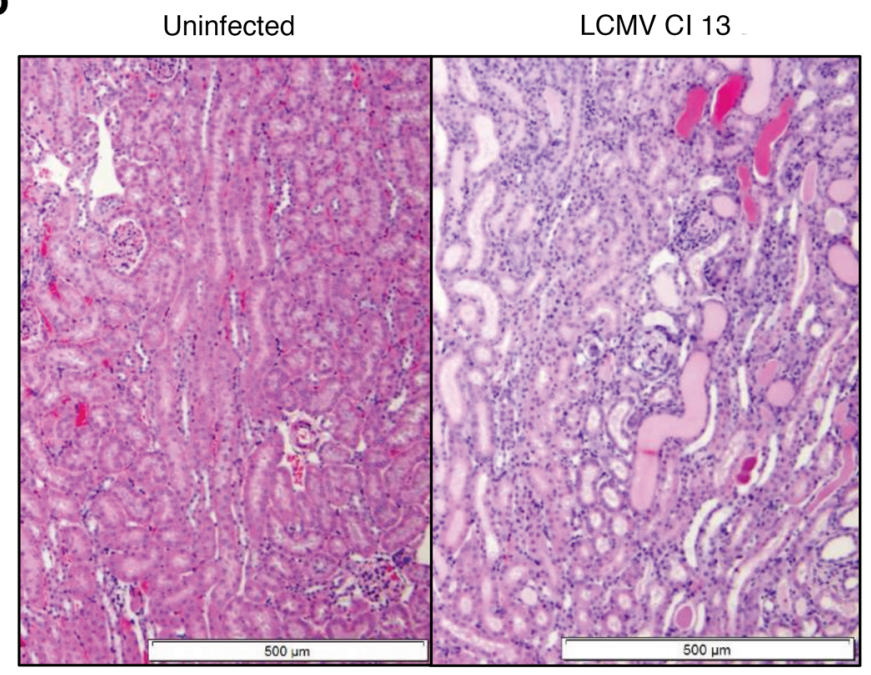

E

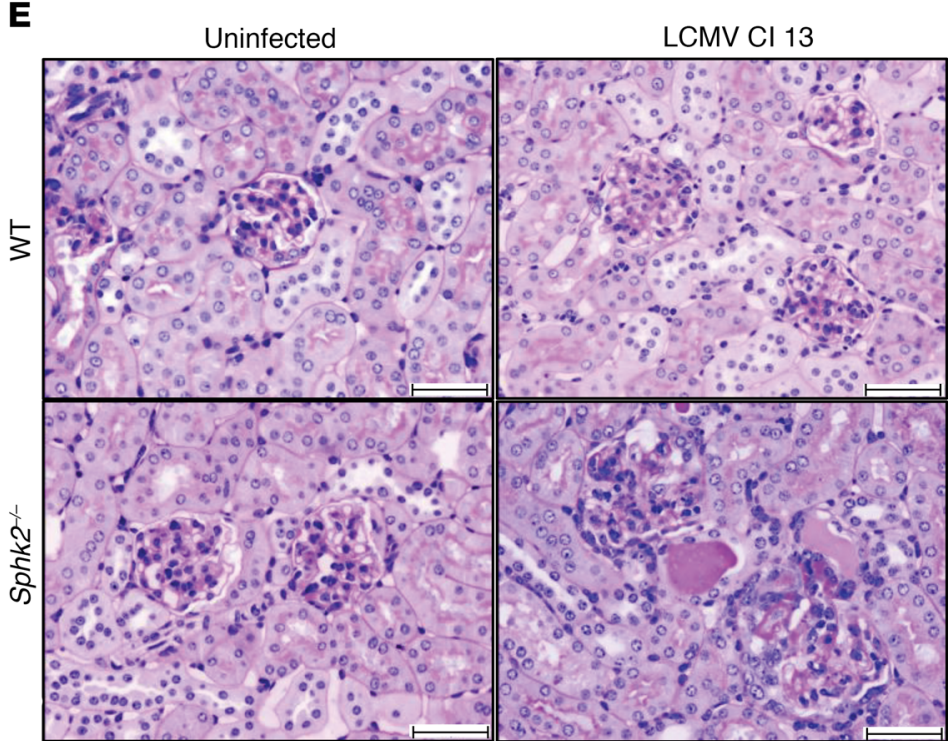

$\leq$

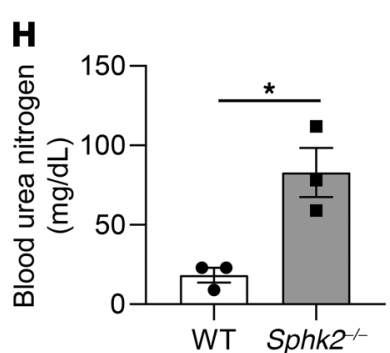

K

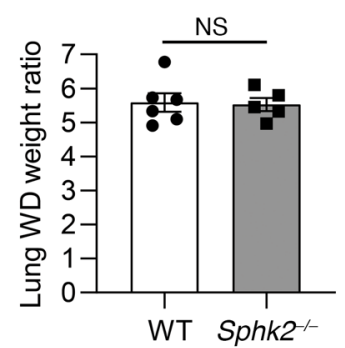


Figure 1. SphK2-deficient mice, but not SphK1-deficient mice, succumb to LCMV Cl 13 infection via kidney disease. (A) WT (squares), Sphk1 $1^{-1-}$ (triangles), and Sphk2 $2^{-1-}$ (circles) mice were infected with LCMV CI 13 and monitored for survival ( $n=4-5$ mice/group). (B) WT mice were infected with $2 \times 10^{6}$ PFU LCMV CI 13 (black squares), and Sphk2-/- mice were infected with $4 \times 10^{5}$ (inverted triangles), $1 \times 10^{6}$ (diamonds), or $4 \times 10^{6}$ (white squares) PFU LCMV CI 13 ( $n=4-5$ mice/group). Survival was monitored for 30 days. (C) Survival of Sphk2-/- mice was assessed following LCMV Cl 13 (triangles) or Arm (circles) infection ( $n=5$ mice/group). (D) Sphk2-/- mice were uninfected $(n=3)$ or infected with LCMV Cl $13(n=8)$. At 18 dpi, mice were sacrificed for histological analysis. Kidneys from uninfected or infected Sphk2 $2^{-1-}$ mice were stained with H\&E. Scale bars: $500 \mu \mathrm{m}$. (E) WT and Sphk2-/- mice were uninfected $(n=3)$ or infected with LCMV CI $13(n=8)$, and at $18 \mathrm{dpi}$, kidneys were stained with PAS. Scale bars: $50 \mu \mathrm{m}$. (F-H) WT and Sphk2-- mice were infected with LCMV CI 13 ( $n=3-5$ mice/group). At 15-17 dpi, when Sphk2 ${ }^{-/-}$mice developed severe morbidity, serum was used for biochemistry profile analysis of total protein (F), albumin (G), and BUN (H). (I-K) WT and Sphk2-/- ( $n=5-6$ mice/group) mice were infected with LCMV CI 13. At $14 \mathrm{dpi}$, mice were administered EB dye i.v., and EB levels were measured in kidney (I) and lung (J) tissues. At $14 \mathrm{dpi}$, the wet/dry (WD) weight ratio for lung tissue was assessed (K). ${ }^{*} P \leq 0.05 ;{ }^{* *} P \leq 0.01$; ${ }^{* *} P \leq 0.001$, bidirectional, unpaired Student's $t$ test. Data are representative of 2-3 independent experiments.

infection in mice and that both enzymes constitute proviral factors during IAV infection (39). SphK1 and SphK2 have also been implicated in the functioning of human T helper 17 (Th17) cells via promotion of IL-17 expression (40). Nevertheless, the role of SphKs in regulating host immune responses to viral infections is poorly understood.

In this study, we investigated whether the SphKs regulate immune responses to chronic LCMV infection. SphK2-deficient mice, but not SphK1-deficient mice, succumbed to LCMV Cl 13 infection following nephropathy due to excessively elevated $\mathrm{T}$ cell activity. SphK2 was shown to intrinsically inhibit $\mathrm{CD} 4^{+} \mathrm{T}$ cell proliferation and activity during LCMV Cl 13 infection, which subsequently suppressed $\mathrm{CD} 8^{+} \mathrm{T}$ cell responses. Importantly, oral administration of an SphK2-selective inhibitor promoted the termination of viral persistence. The results indicate that SphK2 displays an immune regulatory function that determines the fate of antiviral $\mathrm{T}$ cell responses and virus persistence and that $\mathrm{SphK} 2 \mathrm{can}$ be targeted as an immunotherapeutic to chronic viral infections.

\section{Results}

Genetic ablation of SphK2 results in kidney disease and subsequent mortality of mice upon LCMV Cl 13 infection. Although the SphKs are known to influence diverse cellular conditions and disease progression in several viral infections, the impact that SphKs have on persistent viral infections is unclear. In order to investigate this, we infected SphK1-deficient $\left(S p h k 1^{-/}\right)$, SphK2-deficient (Sphk2--), and C57BL/6 WT mice with LCMV Cl 13. Unexpectedly, we observed that $S p h k^{--}$mice displayed severe morbidity, including lethargy, within 1 to 2 weeks of infection (Supplemental Figure 1A; supplemental material available online with this article; https://doi.org/10.1172/JCI125297DS1). All Sphk2-- mice succumbed to the virus by 20 days post infection (dpi) (Figure 1A). In contrast, $S p h k 1^{-/-}$mice, as well as WT mice, survived $\mathrm{Cl}$ 13 infection (Figure 1A). Sphk1/- mice also did not have differences in LCMV Cl 13 serum titers from WT as long as 35 days after infection (data not shown). Sphk2-- mice had increased fluid retention, which correlated with an increase in weight in the mice shortly before death (Supplemental Figure 1B). These results suggest that SphK1 and SphK2 display distinctly differential functions during $\mathrm{LCMV} \mathrm{Cl} 13$ infection.

While infection of mice with $2 \times 10^{6} \mathrm{PFU}$ of LCMV Cl 13 has been well established in this persistent virus infection model without causing immune pathology, infection with $4 \times 10^{5} \mathrm{PFU}$ of LCMV Cl 13 has been shown to cause lethality in approximately $30 \%$ of infected mice (41). Therefore, we tested to determine whether the mortality of infected $S p h k 2^{--}$mice is altered by the viral dose. For this purpose, Sphk2- mice were infected with LCMV $\mathrm{Cl} 13$ at $4 \times 10^{5}, 1 \times 10^{6}$, or $4 \times 10^{6} \mathrm{PFU}$. All infected Sphk2 ${ }^{--}$mice at these doses died in a similar manner (Figure 1B), suggesting that the observed lethal phenotype is not dependent on differences in viral titer in this model of chronic viral infection. Furthermore, it is a possibility that a complete deficiency of SphK2 is not required for mortality. Therefore, we crossed WT and Sphk2 $\%$ mice to generate $S p h k 2$ heterozygous $\left(S p h k 2^{+/}\right)$mice, which were then infected with LCMV Cl 13. Sph $2^{+/-}$mice did not experience the same mortality associated with Sphk2- mice (Supplemental Figure 1C), and these mice exhibited a weight change pattern similar to that of WT mice (Supplemental Figure 1B). These results indicate that deletion of both alleles of the Sphk2 gene is required to generate the mortality and morbidity seen following LCMV Cl 13 infection.

The clone 13 strain of LCMV was derived from the Arm strain of LCMV. LCMV Arm establishes an acute infection and is cleared within 10 days of infection (8). Since LCMV Arm has the same antigenic targets as LCMV Cl 13, we sought to determine whether the morbidity and mortality seen in mice lacking SphK2 was specific to chronic viral infections. To test this, Sphk2- mice were infected with $2 \times 10^{6} \mathrm{PFU}$ of LCMV Arm. While Sphk2-- mice again succumbed to infection with LCMV Cl 13, no mortality was observed when the mice were infected with LCMV Arm (Figure 1C). This result indicates that the mortality observed in Sphk2-- mice is LCMV strain dependent and associated with systemic, persistent LCMV Cl 13 infection.

LCMV is normally a noncytopathic virus, which raises the question of why SphK2-deficient mice died following LCMV Cl 13 infection. To address this, $S p h 2^{--}$mice were infected with LCMV $\mathrm{Cl} 13$ and euthanized before death. Tissue samples were then processed for histologic assays. The analyses using H\&E (Figure 1D) and periodic acid-Schiff (PAS) (Figure 1E) staining indicated increased immune cell infiltration into the kidneys, glomerulomegaly, cellular proliferation and mesangial expansion, dilated renal tubules, cell necrosis (loss of integrity of brush border) and accumulation of pink hyaline material (Tamm Horsfall protein), in the kidneys of LCMV-infected, SphK2-deficient mice (Figure 1, D and E). As a result, the potential cause of death was attributed to kidney failure and the lesions identified as glomerulonephritis and acute tubular necrosis. In support of this, Sphk2-- mice showed an increase in fluid retention in the peritoneal cavity as a sign of ascites as well as visible discoloration of the kidneys. Furthermore, biochemical analysis of the serum from infected Sphk2 ${ }^{--}$mice taken before death showed a decrease in total protein (Figure 1F) and albumin (Figure 1G) and an increase in blood urea nitrogen (BUN) (Figure 1H) compared with that of infected WT mice. In addition, 
changes in sodium, chloride, and potassium (Supplemental Figure $2, \mathrm{~A}-\mathrm{C}$ ) suggest an electrolyte imbalance and secondary hyperaldosteronism state as a potential cause for the fluid retention. The altered profiles on histology and serology are similar to the known clinical presentation of glomerulonephritis with nephrotic syndrome $(42,43)$. However, Sphk2 ${ }^{-/-}$mice did not have significantly different levels of globulin, glucose, and alanine aminotransferase (Supplemental Figure 2, D-F), which suggests that liver function was intact and not the cause of ascites. Additionally, an Evans blue (EB) assay was performed to assess vascular permeability in these mice. While Sphk2 ${ }^{--}$mice had increased vascular leakage in the kidney (Figure 1I), this was not observed in the lungs (Figure 1J). Furthermore, no change occurred in the ratio of wet/dry weight for the lungs (pulmonary edema) of $S p h k 2^{-/-}$mice when compared with that of WT mice (Figure 1K), supporting the premise that heart function was not affected. Finally, unlike the kidney, other tissues, such as liver, lung, pancreas, brain, and heart, displayed little or only mild immune cell infiltration in the infected mice, and no difference was noted between LCMV-infected WT and Sphk2 ${ }^{-1-}$ mice for these tissues in histologic analysis (data not shown). Together, our results strongly suggest that $S p h k 2^{-/-}$mice succumb to LCMV Cl 13 infection due to kidney failure from glomerulonephritis.

SphK2 deficiency induces T cell-mediated immunopathology upon LCMV Cl 13 infection. Immune cell infiltration into the kidneys of infected $S p h k 2^{--}$mice suggests a possible role of the immune system in the observed mortality. Furthermore, the significant morbidity and mortality of the $S p h k 2^{-/-}$mice were observed only after the first week of infection (Figure 1A and Supplemental Figure 1). This suggests that the adaptive immune response may directly contribute to the pathogenic consequence of LCMV Cl 13 infection in these mice. Indeed, LCMV Cl 13 infection-induced mortality was reported to be associated with the dysfunction of virusspecific $\mathrm{CD}^{+} \mathrm{T}$ cells $(44,45)$. Thus, we analyzed virus-specific $\mathrm{CD}^{+} \mathrm{T}$ cell responses in WT and Sphk2-/- mice upon LCMV Cl 13 infection. To analyze virus-specific $\mathrm{CD}^{+} \mathrm{T}$ cells, we used an LCMV immunodominant epitope $\mathrm{GP}_{33-41}$-specific, fluorochrome-labeled, MHC-I-restricted tetramer $\left(\mathrm{GP} 33 \mathrm{Tet}^{+}\right)$as well as restimulation of cells with $\mathrm{GP}_{33-41}$ peptide (GP33/CD8 ${ }^{+}$). SphK2 deficiency substantially increased the generation of GP33 $\mathrm{Tet}^{+} \mathrm{CD}^{+} \mathrm{T}$ cells at $7 \mathrm{dpi}$ (Figure 2A). Simultaneously, IFN- $\gamma$-producing GP33/CD ${ }^{+}$T cells were found to increase in the spleen of $S p h k 2^{-/-}$mice (Figure 2B). This was also observed with $\mathrm{CD}^{+} \mathrm{T}$ cells specific to other LCMV epitopes, GP276 and NP396 (Supplemental Figure 3, A and B). These responses were even evident at $5 \mathrm{dpi}$, at which time there were increases in the portions of GP33 $\mathrm{Tet}^{+} \mathrm{CD} 8^{+} \mathrm{T}$ cells (Figure 2C), granzyme B-producing GP33 $\mathrm{Tet}^{+} \mathrm{CD}^{+}$(Figure 2D), and IFN- $\gamma$-producing GP33/CD8 ${ }^{+}$T cells (Figure 2E).

The product of the SphK enzymatic reaction, S1P, affects lymphocyte trafficking to lymphoid organs (46). Therefore, we assessed whether the observed phenotype was due to a disruption of virus-specific T cell trafficking in $S p h k 2^{-/-}$mice by analyzing virus-specific $\mathrm{CD}^{+}$responses in a nonlymphoid organ. Similarly to LCMV-specific CD $8^{+} \mathrm{T}$ cell responses in the spleen, the increase in GP33 $\mathrm{Tet}^{+} \mathrm{CD} 8^{+} \mathrm{T}$ cells was observed in the livers of Sphk2-/mice compared with WT mice (Figure $2 \mathrm{~F}$ ). This result suggests that no significant disturbance of $\mathrm{CD}^{+} \mathrm{T}$ cell trafficking occurred due to the absence of SphK2 during LCMV Cl 13 infection.
Since robust $\mathrm{CD}^{+} \mathrm{T}$ cell responses were observed in Sphk2-/mice during LCMV Cl 13 infection, we speculated that the lethality of these mice might be due to excessive $\mathrm{CD} 8^{+} \mathrm{T}$ cell responses following infection. In order to test this, $\mathrm{CD} 8^{+} \mathrm{T}$ cells were depleted before LCMV Cl 13 infection. Depletion of $\mathrm{CD}^{+} \mathrm{T}$ cells rescued $S p h 2^{--}$mice from LCMV infection-induced mortality (Figure $2 \mathrm{G})$. These data indicate that virus-specific, Sphk2-deficient CD8 ${ }^{+}$ $\mathrm{T}$ cell responses become exacerbated following infection, leading to the death of Sphk2-/- mice.

The activation of $\mathrm{CD}^{+} \mathrm{T}$ cells is required to maintain antiviral $\mathrm{CD}^{+} \mathrm{T}$ cell responses during LCMV Cl 13 infection $(20,21)$. Thus, we assessed whether $\mathrm{CD} 4^{+} \mathrm{T}$ cell responses contribute to the mortality of Sphk2-/ mice upon LCMV Cl13 infection. Sphk2-/- mice had significantly more LCMV GP ${ }_{66-77}$ (GP66) epitope-specific CD4 ${ }^{+} \mathrm{T}$ cells compared with WT mice, which was determined by using a fluorochrome-labeled GP66 tetramer (GP66 Tet ${ }^{+}$) at 7 dpi (Figure 3A). $\mathrm{CD}^{+} \mathrm{T}$ cells expressing IFN- $\gamma$ or IL-2, which were measured by ex vivo stimulation with LCMV GP $61-80$ (GP61) peptide (GP61/ $\mathrm{CD} 4^{+}$), significantly increased in the absence of SphK2 following LCMV Cl 13 infection (Figure 3, B and C). Also, a higher number of $\mathrm{CD}^{+} \mathrm{T}$ cells were undergoing active proliferation $\left(\mathrm{Ki}^{+}\right)$in Sphk2/- mice compared with WT mice upon LCMV Cl 13 infection (Figure 3D). In a similar manner to $\mathrm{CD}^{+} \mathrm{T}$ cell responses, a higher frequency of LCMV-specific CD $4^{+} \mathrm{T}$ cells were observed in a nonlymphoid organ, the liver, from $S p h k 2^{-/-}$mice (Figure 3E). These data indicate that SphK2 deficiency also results in enhanced CD4 ${ }^{+}$ $\mathrm{T}$ cell responses following LCMV $\mathrm{Cl} 13$ infection.

LCMV Cl 13 infection was previously reported to eliminate activated $\mathrm{CD} 4^{+} \mathrm{T}$ cells, which affects $\mathrm{CD} 8^{+} \mathrm{T}$ cell function, leading to viral persistence $(5,47)$. However, failure to eliminate activated $\mathrm{CD} 4^{+} \mathrm{T}$ cells could have a deleterious impact on the host during an inflammatory response. Since $S p h k 2^{-/-}$mice have enhanced $\mathrm{CD} 4^{+}$ $\mathrm{T}$ cell responses, we hypothesized that this might contribute to the morbidity and mortality caused by LCMV Cl 13 infection in addition to or in concert with the enhanced $\mathrm{CD}^{+} \mathrm{T}$ cell response. Therefore, we depleted CD4 ${ }^{+} \mathrm{T}$ cells before LCMV Cl 13 infection. Depletion of $\mathrm{CD}^{+} \mathrm{T}$ cells also rescued $S p h k 2^{-\gamma_{-}}$mice from infection-induced lethality (Figure 3F). Of note, Sphk2 $2^{--}$mice generated stronger $\mathrm{CD}^{+} \mathrm{T}$ cell responses to LCMV Arm than the WT controls (Supplemental Figure 4, A and B), while similar $\mathrm{CD} 8^{+} \mathrm{T}$ cell responses to Arm were observed (Supplemental Figure 4, C and D). This suggests that SphK2 may have a direct function on the overall response of $\mathrm{CD}^{+}{ }^{+} \mathrm{T}$ cells to a viral infection, but differences in how the LCMV Arm and $\mathrm{Cl} 13$ infections progress lead to differential effects on the host. Taken together, these results indicate that SphK2 deficiency induces an enhanced $\mathrm{CD} 4^{+} \mathrm{T}$ cell response, which contributes to

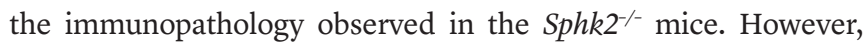
despite the increased $\mathrm{T}$ cell immunity, viral titers did not significantly decrease in the spleen of $S p h k 2^{-/-}$mice at 7 dpi (Supplemental Figure 5). This suggests that SphK2-deficient mice became moribund from the immune pathology soon after infection, yet the systemic spread of LCMV Cl 13 was not prevented.

Since $S p h k 2^{-/-}$mice succumbed to LCMV Cl 13 infection due to immune pathology with kidney disease, we further assessed the populations of immune cells infiltrating into the kidneys upon infection. We discovered an increase in the percentages and numbers of both GP66 $\mathrm{Tet}^{+} \mathrm{CD}^{+} \mathrm{T}$ cells and GP33 $\mathrm{Tet}^{+}$ 
A

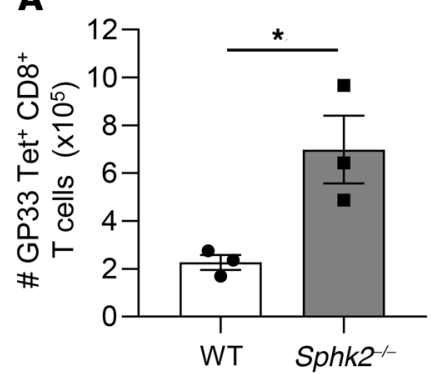

B
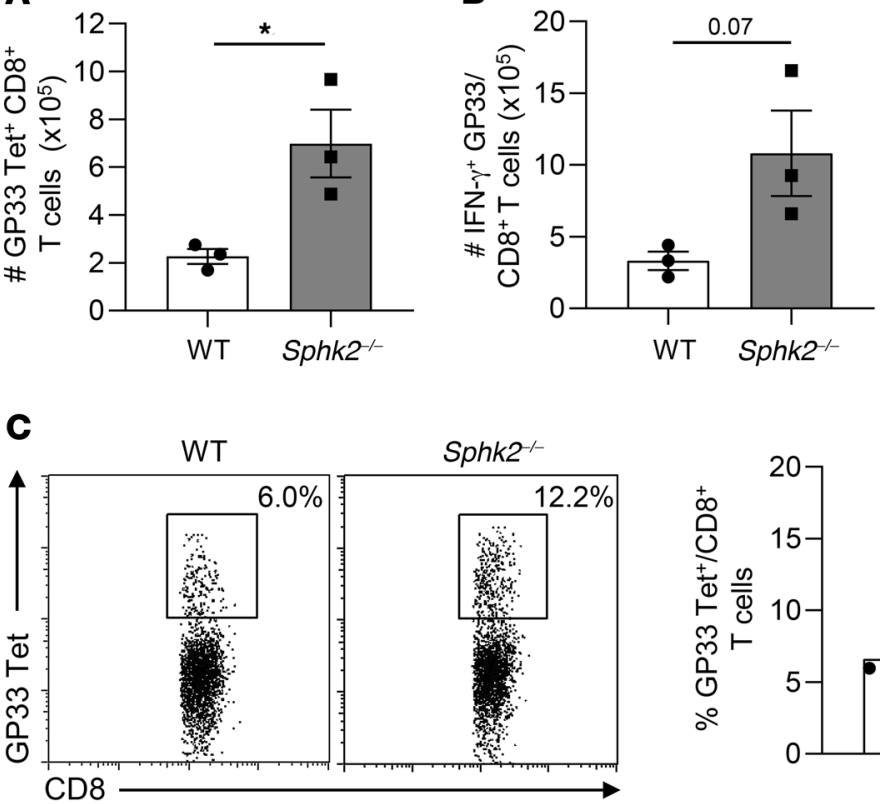

D

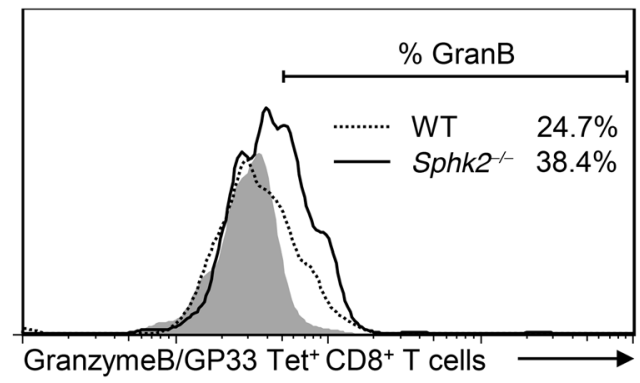

E

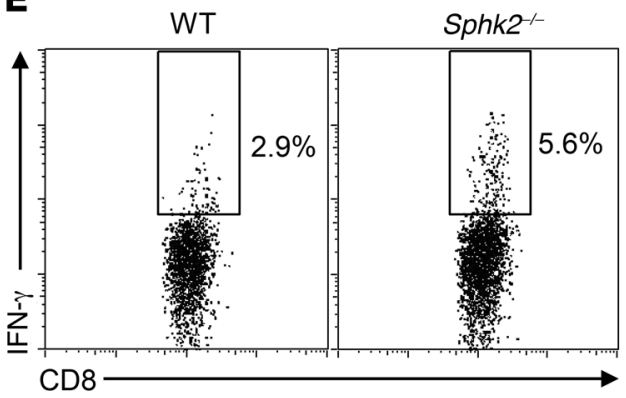

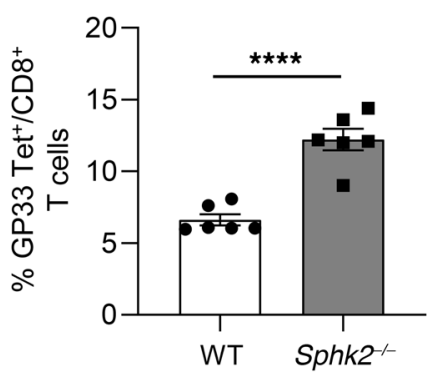
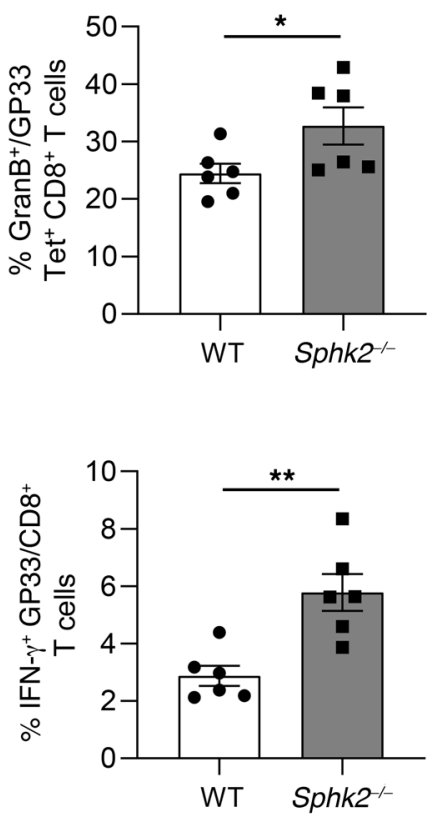

$\mathbf{F}$

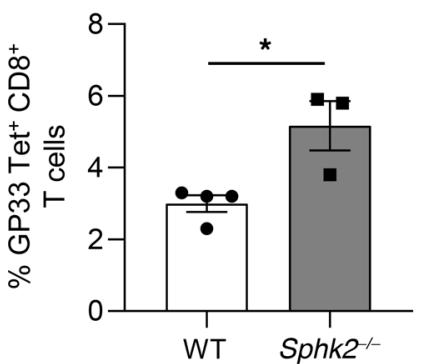

G

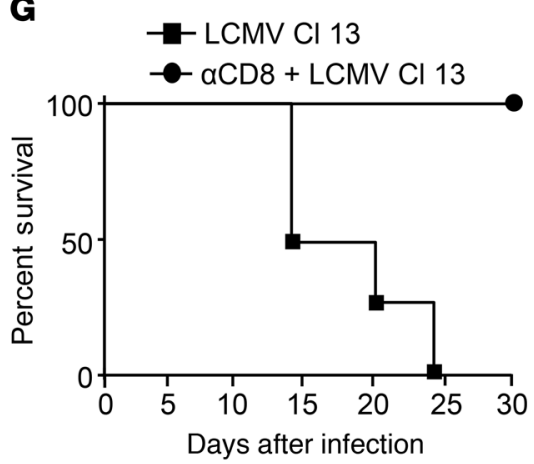

Figure 2. Deletion of SphK2 causes lethal $\mathrm{CD8}^{+} \mathrm{T}$ cell-mediated immunopathology upon LCMV Cl 13 infection. (A and B) WT or Sphk2 $2^{-1-}$ mice ( $n=3$ mice) group) were infected with LCMV CI 13. (A) The total number of LCMV GP33 ( $\left.\mathrm{CP}_{33-47}\right)$ tetramer ${ }^{+}$CD8 ${ }^{+} \mathrm{T}$ cells in the spleen were analyzed $7 \mathrm{dpi}$ by flow cytometry. (B) Splenocytes were stimulated with GP33 peptide, and the number of IFN $\gamma$-producing $\mathrm{CD} 8^{+} \mathrm{T}$ cells was determined by flow cytometry. (C-E) WT or Sphk2 $2^{-1-}$ mice ( $n=6$ mice/group) were infected with LCMV $\mathrm{Cl} 13$ and analyzed $5 \mathrm{dpi}$ for the percentage of GP33 $\mathrm{Tet}^{+} \mathrm{CD}^{+} \mathrm{T}$ cells (C). Splenocytes from these mice were stimulated with GP33 peptide, and they were then analyzed for the percentage of GP33 Tet $^{+}$cells expressing granzyme $B(D)$ and total $C D 8^{+} T$ cells expressing IFN- $\gamma(\mathbf{E})$. (F) Frequency of GP33 $\mathrm{Tet}^{+}$ $\mathrm{CD}^{+} \mathrm{T}$ cells was determined out of the total CD8 ${ }^{+}$ populations in the livers of LCMV Cl 13-infected mice at $7 \mathrm{dpi}$ ( $n=3-4$ mice/group). (C) Survival curve of Sphk2 ${ }^{-/-}$mice ( $n=4-5$ mice/group) after depletion ( $\alpha$ CD8 + LCMV Cl 13) or no depletion (LCMV Cl 13) of CD8 ${ }^{+}$T cells is shown. ${ }^{*} P \leq 0.05 ;{ }^{*} P \leq 0.01 ;{ }^{* * *} P \leq$ 0.0001 , bidirectional, unpaired Student's $t$ test. Data are representative of 2-3 independent experiments.

$\mathrm{CD}^{+} \mathrm{T}$ cells (Supplemental Figure 6, A and B). However, we observed a decrease in the percentage of $\mathrm{B}^{220^{+}}$cells with no change in number (Supplemental Figure 6C). Furthermore, there was a significant increase in neutrophils (Ly6G $\mathrm{Ly}^{+} \mathrm{C}^{+}$cells) (Supplemental Figure 6D). There was an increase in the number but not percentage of $\mathrm{CD} 11 \mathrm{~b}^{+}$cells, while we observed no altered population of CD11 $\mathrm{c}^{+}$ cells (Supplemental Figure 6, E and F). Therefore, multiple immune cells, such as $\mathrm{CD} 4^{+}$and $\mathrm{CD}^{+} \mathrm{T}$ cells and neutrophils, infiltrate into kidneys, which may greatly contribute to the observed nephritis in Sphk2-/ mice.

The expression of SphK2 in $C D 4^{+} T$ cells, but not in $C D 8^{+} T$ cells, is necessary for the inhibition of $\mathrm{T}$ cell expansion following LCMV Cl 13 infection. Our data show that SphK2 modulates both $\mathrm{CD}^{+}$and $\mathrm{CD} 8^{+} \mathrm{T}$ cell expansion and activity during LCMV Cl 13 infection. We next sought to determine whether the suppressive functions of SphK2 on T cell responses during LCMV Cl 13 infection originated from an intrinsic, cellular role, or an extrinsic, distal source. To this end, we generated SphK2-deficient, GP33 or GP61-specific T cell receptor (TCR) Tg mice. First, SphK2-sufficient $\left(S p h k 2^{+/+}\right)$or Sphk2 $2^{--}$ Thy1.1 $1^{+}$GP33/CD8 ${ }^{+} \mathrm{T}$ cells were adoptively transferred into WT mice (Figure 4A), which were subsequently infected with LCMV $\mathrm{Cl} 13$. At 8 dpi, the expansion of the adoptively transferred GP33-specific $\mathrm{CD} 8^{+} \mathrm{T}$ cells was assessed based on their Thy1.1 congenic marker. This adoptive transfer system allowed us to monitor the specific effects SphK2 deficiency had on 
$\mathrm{CD}^{+} \mathrm{T}$ cells in the absence of external SphK2-deficient factors, such as SphK2-deficient innate cells. Sphk2-/- CD8 ${ }^{+} \mathrm{T}$ cells did not accumulate to a higher level than $S p h k 2^{+/+} \mathrm{CD} 8^{+} \mathrm{T}$ cells upon LCMV $\mathrm{Cl} 13$ infection (Figure 4B). This indicates that SphK2 functions as an extrinsic factor in the suppression of $\mathrm{CD}^{+} \mathrm{T}$ cell responses. To support this, we performed another set of adoptive transfer experiments: Sphk2+/+ Thy1.1+ GP33/CD8 ${ }^{+}$T cells were adoptively transferred into either WT or $S p h k 2^{-/}$mice. These mice were then infected with $\mathrm{LCMV} \mathrm{Cl} \mathrm{13,} \mathrm{and} \mathrm{the} \mathrm{expansion} \mathrm{of} \mathrm{transferred}$ GP33-specific $\mathrm{CD}^{+} \mathrm{T}$ cells was monitored and compared. The portion of reactive virus-specific $\mathrm{CD} 8^{+} \mathrm{T}$ cells was significantly increased after transfer into a $S p h k 2^{-/-}$environment versus a WT environment, indicating an extrinsic role for SphK2 in the case of $\mathrm{CD}^{+} \mathrm{T}$ cells (Supplemental Figure 7A).

Subsequently, we examined the intrinsic or extrinsic role of SphK2 in the enhanced CD $4^{+} \mathrm{T}$ cell responses. Unlike $\mathrm{CD} 8^{+} \mathrm{T}$ cells, when $S p h k 2^{+/+}$or Sphk2 $2^{--}$CD $45.1^{+}$GP61/CD4 ${ }^{+}$T cells were adoptively transferred into WT mice followed by infection with LCMV Cl 13 (Figure 4C), LCMV-specific Sphk2-- CD4 $4^{+}$T cells expanded significantly more than $S p h k 2^{+/+} \mathrm{CD} 4^{+} \mathrm{T}$ cells (Figure 4, $\mathrm{D}$ and $\mathrm{E})$. This indicates that SphK2 functions in a CD4 ${ }^{+} \mathrm{T}$ cellintrinsic manner to negatively regulate $\mathrm{CD}^{+} \mathrm{T}$ cell expansion

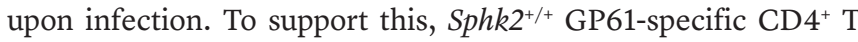
cells were adoptively transferred into WT or $S p h k 2^{-{ }^{-}}$mice. The Sphk2 ${ }^{+/+} \mathrm{CD}^{+} \mathrm{T}$ cells did not expand differentially in either condition, which confirms the $\mathrm{CD} 4^{+} \mathrm{T}$ cell-inherent, suppressive function of SphK2 (Supplemental Figure 7B).

While our data show that SphK2 regulates the expansion of $\mathrm{CD}^{+}{ }^{+} \mathrm{T}$ cells, they do not directly indicate whether SphK2 affects the proliferation of these $\mathrm{CD} 4^{+} \mathrm{T}$ cells or regulates an increase in their number and responsiveness via other means. To determine this, we performed an in vitro proliferation assay. BM-derived DCs (BM-DCs) were infected with LCMV Cl 13. CFSE-stained Sphk2+/+ or Sphk2-/- GP61-specific CD $4^{+}$T cells were then incubated with the infected BM-DCs. After 5 days of incubation, we analyzed the proliferation of these $\mathrm{CD} 4^{+} \mathrm{T}$ cells, which was judged by dilution of CFSE. Sphk2 $2^{--} \mathrm{CD}^{+} \mathrm{T}$ cells proliferated at a higher rate than

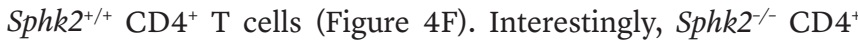
$\mathrm{T}$ cells also proliferated better than $S p h k 2^{+/+} \mathrm{CD} 4^{+} \mathrm{T}$ cells when BM-DCs, mounted with GP61 peptide, were stimulated by the TLR7 ligand loxoribine in the absence of LCMV (Supplemental Figure 8). Thus, these data indicate that SphK2 intrinsically suppresses $\mathrm{CD} 4^{+} \mathrm{T}$ cell proliferation.

The findings led us to hypothesize that SphK2 regulation occurs in $\mathrm{CD}^{+} \mathrm{T}$ cells in order to lead to the $\mathrm{CD} 4^{+} \mathrm{T}$ cell-intrinsic effects on expansion. Therefore, we assessed the activation (phosphorylation) of SphK2 in total splenocytes and CD $4^{+} \mathrm{T}$ cells from mice upon infection with LCMV. The phosphorylation levels of SphK2 appear to increase in total splenocytes at 8 dpi in $\mathrm{Cl}$ 13 or Arm-infected mice compared with those from uninfected mice (Figure 4G). Importantly, the activation of SphK2 was also increased in $\mathrm{CD}^{+} \mathrm{T}$ cells upon LCMV Arm or Cl 13 infection (Figure $4 \mathrm{H})$. An increase in the overall SphK2 levels was also observed in splenocytes and $\mathrm{CD}^{+} \mathrm{T}$ cells following LCMV infection (Supplemental Figure 9). The increased SphK2 phosphorylation following Arm infection may explain the increased $\mathrm{CD} 4^{+} \mathrm{T}$ cell response detected in Arm-infected, SphK2-deficient mice (Supplemental
Figure 4, A and B). These data indicate that SphK2 is activated in $\mathrm{CD}^{+} \mathrm{T}$ cells during viral infection, supporting a regulatory role for SphK2 in CD $4^{+} \mathrm{T}$ cells responses.

However, these results do not directly explain why we observed increases in $\mathrm{CD}^{+} \mathrm{T}$ cell responses in addition to $\mathrm{CD} 4^{+} \mathrm{T}$ cell responses. Since $\mathrm{CD} 4^{+} \mathrm{T}$ cells often affect $\mathrm{CD} 8^{+} \mathrm{T}$ cell responses to viral infection $(5,22)$, we tested the potential for $\mathrm{CD} 4^{+}-\mathrm{CD}^{+}$ T cell interactions. Therefore, we adoptively transferred $S p h k 2^{+/+}$ or Sphk2-/ CD $45.1^{+}$GP61/CD4 ${ }^{+}$T cells into WT mice to determine whether these $\mathrm{CD} 4^{+} \mathrm{T}$ cells could differentially affect endogenous

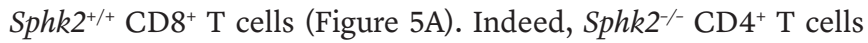
increased endogenous GP33/CD8 ${ }^{+} \mathrm{T}$ cell responses compared with $S p h k 2^{+/+} \mathrm{CD} 4^{+} \mathrm{T}$ cells, which was determined by enhanced effector functions in the secretion of IFN- $\gamma$, TNF- $\alpha$, and granzyme B (Figure 5, B-D). Collectively, these results suggest that LCMV $\mathrm{Cl} 13$ infection markedly increases the expression and activation of SphK2 in $\mathrm{CD}^{+} \mathrm{T}$ cells, leading to a suppression of the proliferation and function of these T cells. In turn, these suppressed $\mathrm{CD} 4^{+}$ $\mathrm{T}$ cells cannot stimulate a strong $\mathrm{CD}^{+} \mathrm{T}$ cell response.

SphK2 regulates gene transcriptional and cell cycle events in $C D 4^{+}$ $T$ cells. In order to determine what effect SphK2 activation has on $\mathrm{CD}^{+} \mathrm{T}$ cells during viral infection, we performed an RNA-Seq experiment. Sphk2 $2^{+/+}$or $S p h k 2^{-/-}$CD $45.1^{+}$GP61/CD $4^{+}$T cells were transferred into WT mice, followed by infection with LCMV Cl 13. At $7 \mathrm{dpi}, \mathrm{CD} 45.1^{+} \mathrm{CD} 4^{+} \mathrm{T}$ cells were isolated from the infected mice to extract RNA. Following RNA-Seq, 55 million single-end reads were aligned via HiSat2 to the Mus musculus reference genome and compared using DESeq2 differential sequencing analysis. We found 544 genes to be differentially expressed (DE) with an FDR below 0.5. Of these, half ( 272 genes) were upregulated and the other half (272 genes) were downregulated in virus-specific, Sphk2 $2^{-/-} \mathrm{CD}^{+} \mathrm{T}$ cells when compared with Sphk2 $2^{+/+} \mathrm{CD} 4^{+} \mathrm{T}$ cells (Figure 6, A and B). Several genes with the highest fold changes encode proteins known to regulate immune signaling as well as cellular proliferation (Figure 6C). Raw and normalized data have been made available in the NCBI's Gene Expression Omnibus (GEO GSE155030). To further assess the regulatory role of SphK2 in $\mathrm{CD}^{+} \mathrm{T}$ cell responses, gene set enrichment analysis (GSEA) was performed using gene ontology (GO) and hallmark (Hall) molecular signature databases. An enrichment map incorporating GO pathways revealed super categories, including the regulation of gene transcription, nucleic acid binding, and cell cycle progression, that were upregulated in the SphK2-deficient condition, while gene sets relating to regulation of the immune response and cell surface components were downregulated in SphK2-deficient $\mathrm{CD}^{+} \mathrm{T}$ cells (Figure 6D). Several representative gene sets from these categories and their heatmaps showed specific pathways and genes that are potentially involved in the regulation of $\mathrm{CD} 4^{+}$ $\mathrm{T}$ cells by SphK2 (Figure 6E and Supplemental Figure 10). Overall, these data suggest that in $\mathrm{CD} 4^{+} \mathrm{T}$ cells SphK2 negatively regulates multiple cellular processes, including cellular signaling, transcriptional events, and cell cycling, which may explain the increased virus-specific $\mathrm{CD} 4^{+} \mathrm{T}$ cell responses following ablation of SphK2.

Since TNF- $\alpha$ signaling was shown to be upregulated in virusspecific Sphk2 $2^{--} \mathrm{CD}^{+} \mathrm{T}$ cells (Figure 6E), we used antibodymediated neutralization of TNF- $\alpha$ to determine whether increased TNF- $\alpha$, a well-characterized proinflammatory cytokine, levels were 
A
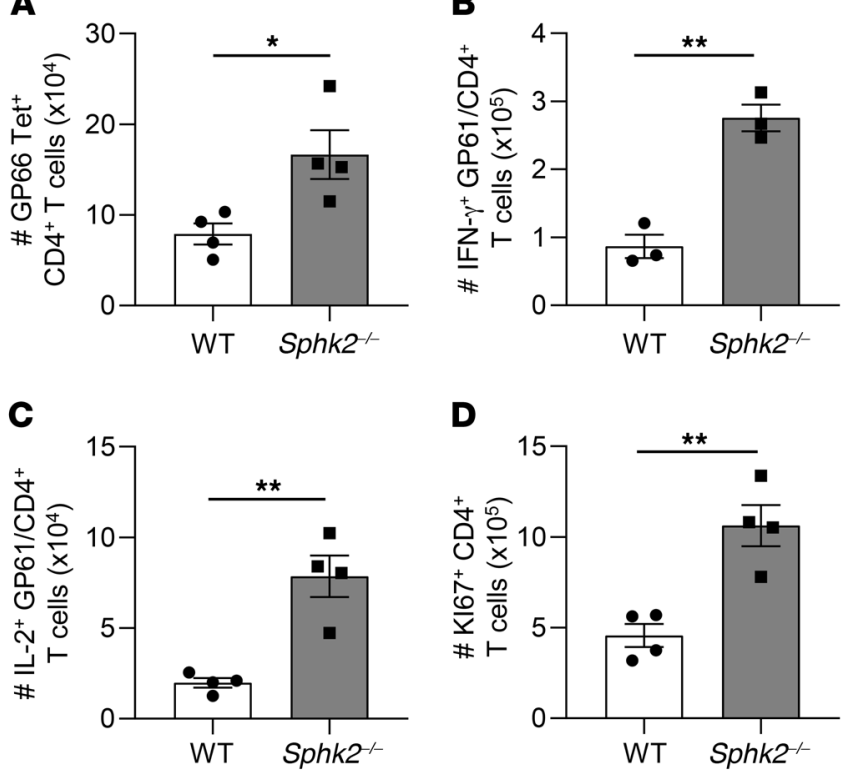

D

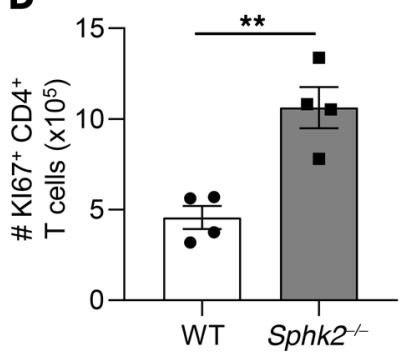

$\mathbf{E}$

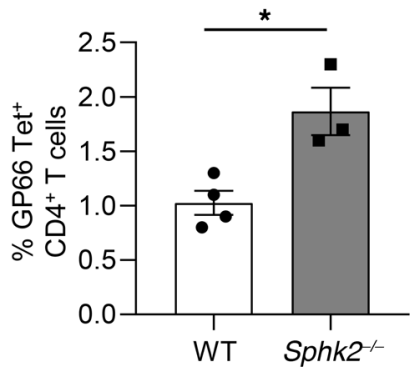

$\mathbf{F}$

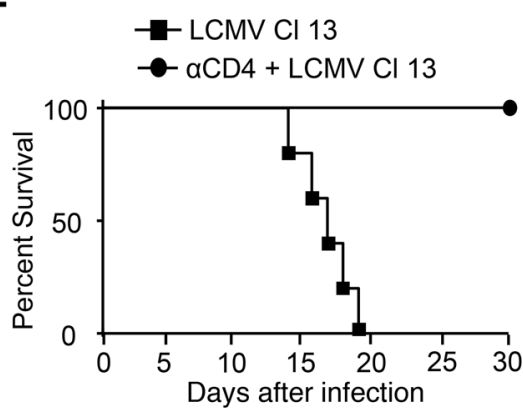

Figure 3. $\mathrm{CD4}^{+} \mathrm{T}$ cell responses against $\mathrm{LCMV} \mathrm{Cl} 13$ are required for SphK2 deficiency-mediated mortality. (A-E) WT or Sphk2/- mice ( $n=3-4$ mice/group) were infected with LCMV CI 13. (A) Number of LCMV GP66 ( $\left(\mathrm{CP}_{66-77}\right)$ tetramer+ ${ }^{+} \mathrm{C}^{+} \mathrm{T}$ cells, (B) number of IFN- $\gamma^{+} \mathrm{CP61}\left(\mathrm{GP}_{61-80}\right)$-specific CD4+ $\mathrm{T}$ cells out of total CD4 ${ }^{+} \mathrm{T}$ cells, (C) number of IL-2+ GP61-specific CD4 ${ }^{+} \mathrm{T}$ cells out of total $\mathrm{CD} 4^{+} \mathrm{T}$ cells, and (D) number of $\mathrm{Ki67^{+ }} \mathrm{CD} 4^{+} \mathrm{T}$ cells in the spleen were assessed at $7 \mathrm{dpi}$ by flow cytometry. (E) Percentage of GP66 tetram$\mathrm{er}^{+} \mathrm{CD} 4^{+} \mathrm{T}$ cells in the livers were also assessed at $7 \mathrm{dpi}$. (F) Survival rate of $5 p h \mathrm{k2}^{-1-}$ mice after depletion ( $\alpha$ CD4 + LCMV CI 13) or no depletion (LCMV CI 13) of CD4 ${ }^{+}$T cells $(n=5$ mice/group) is depicted. ${ }^{*} P \leq 0.05$; ${ }^{* *} P \leq 0.01$, bidirectional, unpaired Student's $t$ test. Data are representative of $2-3$ independent experiments.

leading to the death of Sphk2-- mice following LCMV Cl 13 infection. However, no difference was found between anti-TNF- $\alpha$ and isotype control Ab-treated mice (Supplemental Figure 11). Another well-characterized method of cytotoxicity results from the interaction of Fas, a TNF family member, on the target cell and Fas ligand (FasL) on the immune cell $(48,49)$. Nevertheless, we did not observe a significant change in the survival of Sphk2-- mice following FasL neutralization (Supplemental Figure 11). These data indicate that neither TNF- $\alpha$ nor FasL signaling alone is responsible for the death of Sphk2- mice following LCMV Cl 13 infection.

Transient inhibition of SphK2 restores protective antiviral $T$ cell immunity and controls persistent LCMV infection. Our findings demonstrate that a complete deficiency in SphK2 hinders virusassociated $\mathrm{T}$ cell suppression, which results in excessively escalated $\mathrm{T}$ cell responses causing mortality (Figures 1-5). These results led us to theorize that transient inhibition of SphK2 may improve pro- tective $\mathrm{T}$ cell immunity enough to terminate viral persistence without inducing significant immunopathology. To test this hypothesis, ABC294640 (iSphK2), a potent, well-characterized, orally administrable SphK2-selective inhibitor $(50,51)$, was used to block in vivo SphK2 activation upon LCMV $\mathrm{Cl} 13$ infection. Initially, we sought to observe early T cell responses to LCMV $\mathrm{Cl} 13$ following treatment with $100 \mathrm{mg} / \mathrm{kg}$ iSphK2 (Figure 7A). SphK2 inhibition resulted in an increase in the number of GP33 $\mathrm{Tet}^{+} \mathrm{CD} 8^{+} \mathrm{T}$ cells (Figure $7 \mathrm{~B}$ ) in the spleen as well as an increase in the number of GP66 $\mathrm{Tet}^{+} \mathrm{CD} 4^{+} \mathrm{T}$ cells at 5 dpi (Figure 7C), which suggests that, similarly to genetic ablation, SphK2 inhibitor treatment increases LCMV-specific $\mathrm{T}$ cell responses upon infection. To determine the effects that SphK2 inhibition has on virus-induced $\mathrm{T}$ cell suppression at a later time point, $\mathrm{T}$ cell responses in the spleens of infected, iSphK2-treated mice were evaluated at 40 or $42 \mathrm{dpi}$ (Figure 7D). As seen before, transient SphK2 inhibition resulted in enhanced virus-specific $\mathrm{CD}^{+} \mathrm{T}$ cell (Figure $7 \mathrm{E}$ ) and $\mathrm{CD} 4^{+} \mathrm{T}$ cell responses (Figure 7F) at late time points during chronic infection. Importantly, an increase in IFN $\gamma^{+} \mathrm{TNF}-\alpha^{+}$ GP33 $\mathrm{Tet}^{+} \mathrm{CD} 8^{+} \mathrm{T}$ cells was observed in both the spleen and liver by treatment with iSphK2 at $100 \mathrm{mg} / \mathrm{kg}$ (Figure 7, $\mathrm{G}$ and $\mathrm{J}$ ). The virus-specific $\mathrm{CD} 8^{+} \mathrm{T}$ cell responses displayed an intermediate level when a lower dose (50 $\mathrm{mg} / \mathrm{kg}$ ) of the inhibitor was used. The increase was also seen for IFN $\gamma^{+} \mathrm{TNF}-\alpha^{+} \mathrm{GP} 61 / \mathrm{CD} 4^{+} \mathrm{T}$ cells in the spleen, but not in the liver (Supplemental Figure 12, A and B). Furthermore, we determined the status of exhaustion markers on the virus-specific CD8 ${ }^{+} \mathrm{T}$ cells at $40 \mathrm{dpi}$ following treatment with iSphK2. We observed a trend for decrease in MFIs for LAG-3, PD-1, CD160, and Tim-3 in the spleen (Figure 7, H-I, and Supplemental Figure 12, C and D); a significant decrease of Tim-3 and trend for decreased levels of LAG-3 and CD160, but not PD-1, were noted on the $\mathrm{CD} 8^{+} \mathrm{T}$ cells in the liver (Figure 7, K-L, and Supplemental Figure 12, E and F). These data support the concept that SphK2 inhibition promotes virus-specific $\mathrm{T}$ cell responses in lymphoid and nonlymphoid tissues during LCMV Cl 13 infection.

The promoted $\mathrm{T}$ cell immunity could be partially due to the enhanced stimulation of DCs upon LCMV Cl 13 infection $(9,52)$. However, the activation status of DCs did not increase due to SphK2 inhibition when assessed at 2 dpi (Supplemental Figure 13). These data suggest that transient inhibition of SphK2 activity enhances virus-specific $\mathrm{T}$ cell responses during LCMV Cl 13 infection, which does not seem to depend on DC regulation.

We next determined whether these improved $\mathrm{T}$ cell responses could affect the resolution of viral persistence. Remarkably, oral administration of $100 \mathrm{mg} / \mathrm{kg}$ iSphK2 over the first 7 consecutive days (Figure $8 \mathrm{~A}$ ) resulted in significant reductions in serum viral titers at 42 dpi (Figure $8 \mathrm{~B}$ ) without significant morbidity. Of note, 3 mice that received the inhibitor had no detectable infectious viruses in the serum. Virus titers were also significantly lower in the lungs (Figure 8C) and kidneys (Figure 8D) of iSphK2-treated mice. However, the inhibitor had almost no direct effect on virus 
A
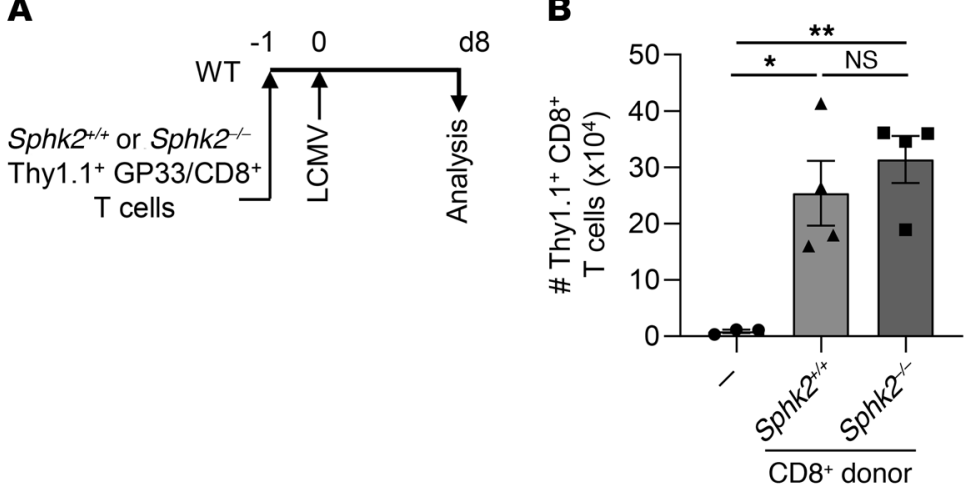

C

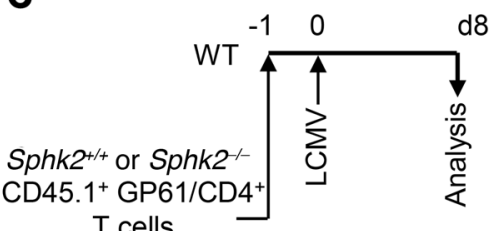

D

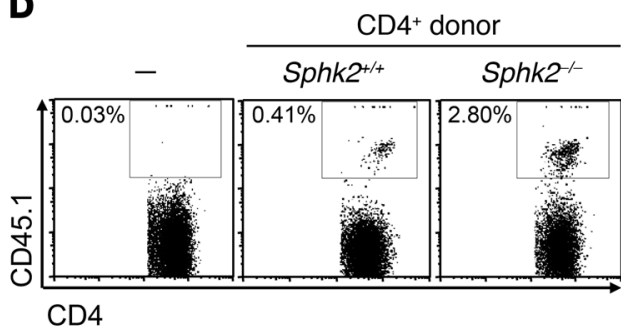

$\mathbf{E}$
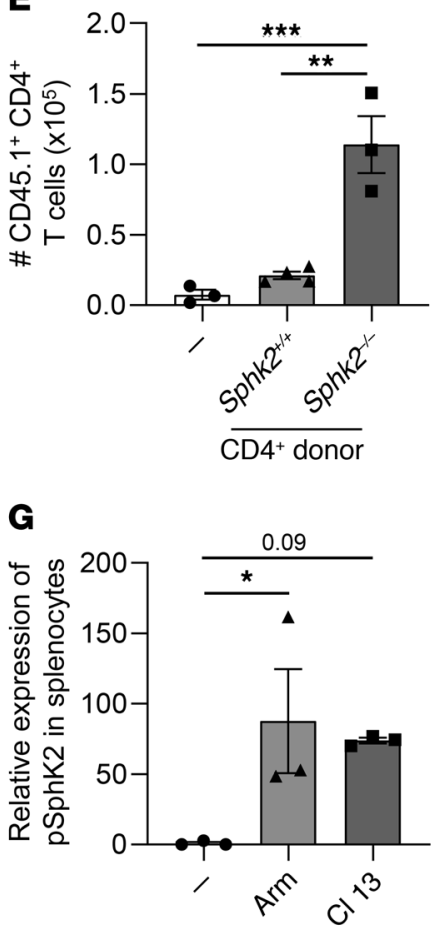

$\mathbf{F}$

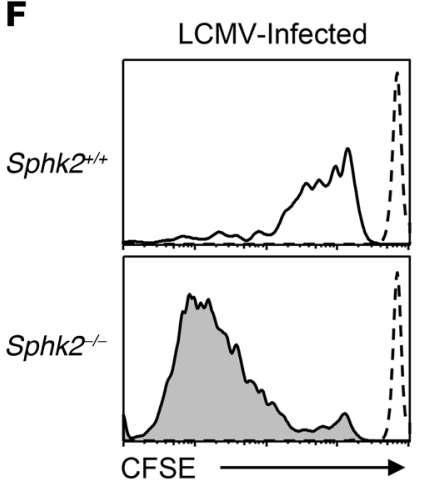

H

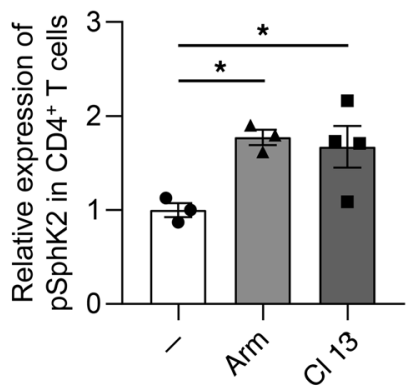

Figure 4. The expression of SphK2 in $C D 4^{+} \mathrm{T}$ cells, but not in CD8 ${ }^{+} \mathrm{T}$ cells, is required for the inhibition of $\mathrm{T}$ cell expansion upon infection. (A and $\mathbf{B}$ ) SphK2-sufficient or -deficient Thy1.1 ${ }^{+}$ GP33/CD8 ${ }^{+}$T cells were adoptively transferred to WT mice which were subsequently infected with LCMV CI 13 ( $n=4$ mice/group). (B) At 8 dpi, the accumulation of Thy $1.1^{+}$CD8 $8^{+}$cells in the spleen was determined. (C-E) (C) SphK2-sufficient or -deficient CD45.1+ GP61/CD4+ $T$ cells were adoptively transferred into WT mice, which were then infected with LCMV CI 13 ( $n=3-4$ mice) group). At $8 \mathrm{dpi}$, the expansion of transferred CD45.1 $1^{+}$CD4 ${ }^{+}$cells ( $\mathbf{D}$ and $\mathbf{E}$ ) was assessed in the spleen. (F) Sphk2+/+ (upper panel; open histogram) or Sphk2-/- (lower panel; filled histogram) GP61-specific CD4+ T cells labeled with CFSE were incubated with LCMV CI 13-infected BM-DCs. 5 days after coculture, the CFSE dilution level was measured by flow cytometry analysis. Dotted lines represent CFSE-stained T cells measured at day $\mathbf{0}$. (G and $\mathbf{H}$ ) Western blot analysis of SphK2 phosphorylation in splenocytes (G) and purified CD4+ $T$ cells $(\mathbf{H})$ from uninfected, LCMV Arm-infected, or LCMV Cl 13-infected mice ( $n=3-4$ mice/group) at 8 dpi. Densitometric analysis is represented as the relative expression to the uninfected group, and $C A P D H$ served as an internal control in each group. ${ }^{*} P \leq 0.05 ;{ }^{* *} P \leq 0.01,1$-way ANOVA with Tukey's post hoc test (B and E) or Dunnett's test (G and $\mathbf{H}$ ). Data are representative of $2-3$ independent experiments.

To further evaluate the applicability of this treatment against chronic viral infections, we sought to determine whether SphK2 inhibition could eradicate virus infection after viral persistence is established. To this end, LCMV Cl 13-infected mice were treated with iSphK2 beginning on 15 (Figure $8 \mathrm{G}$ ) or 20 (Figure 8I) dpi for 7 sequential days. LCMV serum titers were significantly reduced in the mice that received the inhibitor when compared with control mice (Figure 8, $\mathrm{H}$ and J). These data indicate that inhibition of SphK2 can lead to enhanced containment of chronic viral infections even after immunosuppression and viral persistence are established. Overall, these data show that transient inhibireplication at early time points in vivo (Supplemental Figure 14A) or in an in vitro culture system (Supplemental Figure 14B). In order to observe the effect of different doses of iSphK2 following infection, we treated mice as above with $50 \mathrm{mg} / \mathrm{kg}$ or $100 \mathrm{mg} /$ $\mathrm{kg}$ of iSphK2 and monitored viral titers in the serum at $30 \mathrm{dpi}$. We discovered a moderate decrease in viral titers following treatment with $50 \mathrm{mg} / \mathrm{kg}$ iSphK2 when compared with solvent-treated mice and a more pronounced decrease with $100 \mathrm{mg} / \mathrm{kg}$ iSphK2 (Figure $8 \mathrm{E})$. This response was also seen in the kidneys of infected mice at 40 dpi (Figure $8 \mathrm{~F}$ ). tion of SphK2 can improve adaptive T cell responses to LCMV Cl 13 infection in a way that alleviates chronic viral infection by acting on the host immune response instead of the virus directly.

\section{Discussion}

Our results indicate that $\mathrm{SphK} 2$ functions to negatively regulate the function and expansion of $\mathrm{CD}^{+} \mathrm{T}$ cells. During an acute inflammatory response, SphK2 appears to prevent excessive $\mathrm{T}$ cell proliferation; however, LCMV Cl 13 infection increases the activity of SphK2 in $\mathrm{CD} 4^{+} \mathrm{T}$ cells, which prevents the adequate 
A
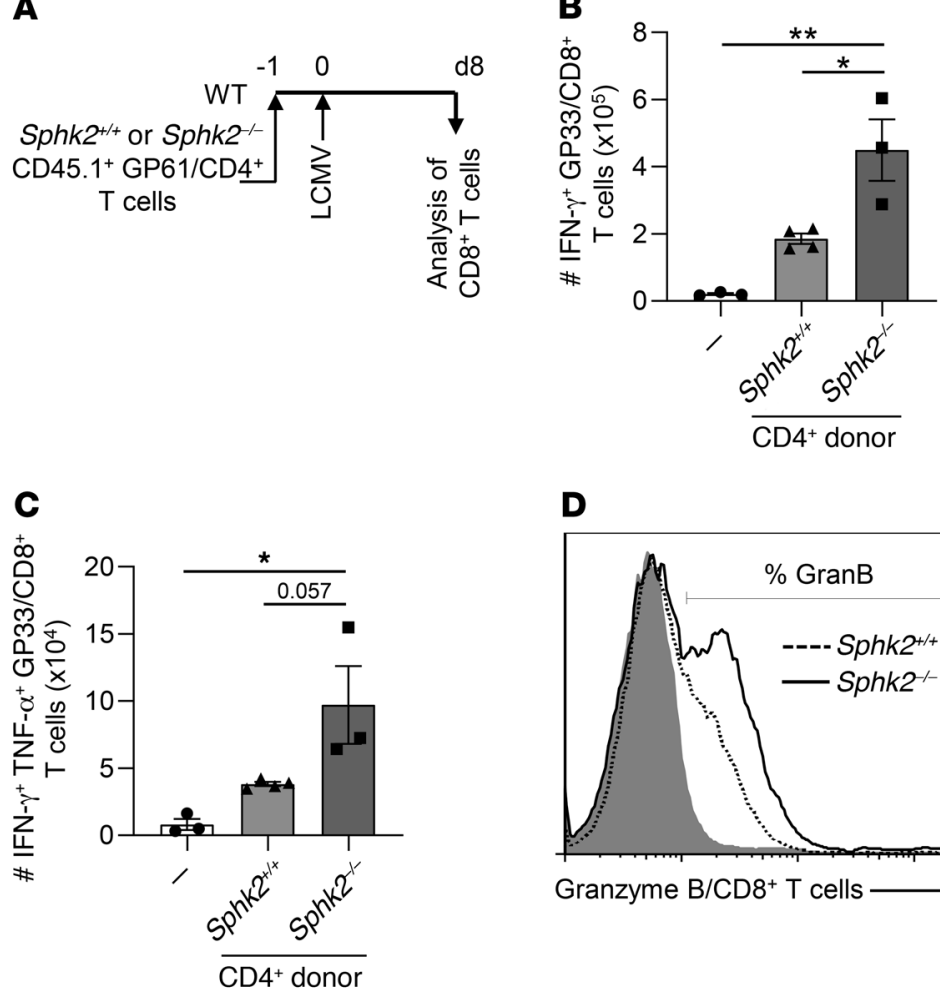

D

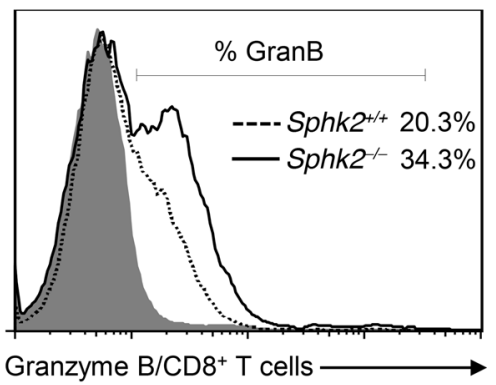

Figure 5. SphK2-deficient $C D 4^{+} T$ cells are able to increase SphK2-sufficient $C D 8^{+} T$ cell responses during $L C M V$ Cl 13 infection. (A-D) SphK2-sufficient or -deficient CD45.1 $1^{+}$ GP61/CD4 ${ }^{+} T$ cells were adoptively transferred into WT mice, which were then infected with LCMV CI 13 ( $n=3-4$ mice/group). At $8 \mathrm{dpi}$, the number of IFN- $\gamma$-positive (B) and IFN- $\gamma /$ TNF- $\alpha$-double-positive (C) endogenous CP33/CD8 ${ }^{+}$T cells were analyzed from the spleens of infected and noninfected mice. Furthermore, the percentages of granzyme B-expressing endogenous $\mathrm{GP3} / \mathrm{CD} 8^{+} \mathrm{T}$ cells (D) were analyzed at this time point. ${ }^{*} P \leq$ $0.05{ }^{* *} P \leq 0.01,1$-way ANOVA with Tukey's post hoc test. Data are representative of 2-3 independent experiments.

activation of the host's adaptive $\mathrm{T}$ cell response, leading to $\mathrm{T}$ cell dysfunction and persistent viral infection. Overall, SphK2 is shown to regulate $\mathrm{T}$ cell responses during viral infection, and transient inhibition of this enzyme is effective in clearing a persistent viral infection.

Although both SphK1 and SphK2 metabolize the formation of S1P from sphingosine, the deficiency of SphK2, but not SphK1, led to lethal immunopathology upon LCMV Cl 13 infection (Figure 1). The difference in the cellular localization of SphK1 (cytosol/ plasma membrane) and SphK2 (mainly in the nucleus) may affect their functions to regulate differential cellular processes $(29,53$, 54). Indeed, SphK1 was reported to interact with TRAF2 in the cytosol to regulate TNF-induced NF- $\mathrm{kB}$ signaling, suggesting the possible role of SphK1 in influencing inflammation (30, 31, 55-58). While the proinflammatory versus antiinflammatory role of SphK2 in arthritis is controversial (59), SphK2 was reported to regulate cytokine signaling $(27,28)$. Interestingly, SphK2 interacts with histone deacetylases (HDAC1 and HDAC2) in the nucleus to regulate gene transcription in cancer cells in vitro (32). SphK2 deficiency was previously found to induce hyperactivated $\mathrm{CD} 4^{+} \mathrm{T}$ cell responses in vitro upon IL-2 administration and in vivo in a murine inflammatory bowel disease model (27). Using gene knockout and
LCMV epitope-specific TCR Tg mouse models, our study demonstrates that SphK2 in $\mathrm{CD}_{4}{ }^{+} \mathrm{T}$ cells, but not $\mathrm{CD} 8^{+} \mathrm{T}$ cells, is necessary for the inhibition of their expansion during virus infection, and SphK2 expression in $\mathrm{CD}^{+} \mathrm{T}$ cells regulates $\mathrm{CD}^{+} \mathrm{T}$ cell responses to infection. Furthermore, SphK2-deficient $\mathrm{CD} 4^{+} \mathrm{T}$ cells were shown to have significant changes in pathways related to transcriptional control, cell cycle progression, and cellular signaling events (Figure 6). Thus, SphK2 appears to regulate several cellular processes, which ultimately lead to an attenuation of antiviral $\mathrm{CD}^{+}$and $\mathrm{CD}^{+} \mathrm{T}$ cell responses. Future studies will be needed to elucidate specific pathways and genes that are directly regulated downstream of SphK2 in CD4 ${ }^{+} \mathrm{T}$ cells.

While we observed enhanced $\mathrm{T}$ cell responses in Sphk2-- mice, no significant change was noted in viral titers between WT and Sphk2-- mice (Supplemental Figure 5). This may partly be due to the systemic nature of LCMV Cl 13, which prevents viral clearance at earlier time points. Furthermore, as SphK2 principally regulates $\mathrm{CD} 4^{+} \mathrm{T}$ cells, the progressively changed host immunity via $\mathrm{CD}^{+} \mathrm{T}$ cells and its maintenance could be critical for ultimate viral clearance. In support of this, SphK2 inhibition did not substantially affect LCMV titers at 10-20 dpi (Supplemental Figure 14A). Therefore, the immune-mediated injury in the kidneys of Sphk2- mice likely causes death of the mice before viral clearance would occur. The exact immunopathological method involved in the mortality of $S p h k 2^{--}$mice is currently unknown. We observed that neutralization of TNF- $\alpha$ or FasL did not prevent mortality (Supplemental Figure 11). The release of perforin by cytotoxic cells is another mediator of cytotoxic damage $(44,60,61)$; however, this molecule has also been shown to play a protective role during LCMV Cl 13 infection $(62,63)$. It is possible that another cytokine/cytotoxic molecule or combination of immunoregulatory molecules is required for the immune-mediated damage observed following depletion of SphK2.

SphK activation or expression was reported to be altered during several viral infection models $(33,35,36,64,65)$. For instance, influenza and measles viruses were reported to increase the level of SphK1, which enhanced the replication and production of viruses. Our data indicate that $\mathrm{LCMV} \mathrm{Cl} 13$ increases the levels of SphK2 and pSphK2 (Figure 4, G and H, and Supplemental Figure 9). However, the inhibition of SphK2 did not change the replication of LCMV in vitro (Supplemental Figure 14B). Our results support the concept that elimination of LCMV Cl 13 by SphK2 inhibition in vivo is due to the progressively escalated protective $\mathrm{T}$ cell responses, not to the direct inhibition of the virus's replication process. The role of SphK2 in host $\mathrm{T}$ cell immunity to other virus infections remains to be investigated.

Recently, families with steroid-resistant nephrotic syndrome were shown to have recessive mutations in a gene encoding S1P lyase, which mediates degradation of S1P $(66,67)$. This suggests that unbalanced S1P metabolism could cause kidney disease. Other investigators also found that SphKs and S1P receptor sig- 
A
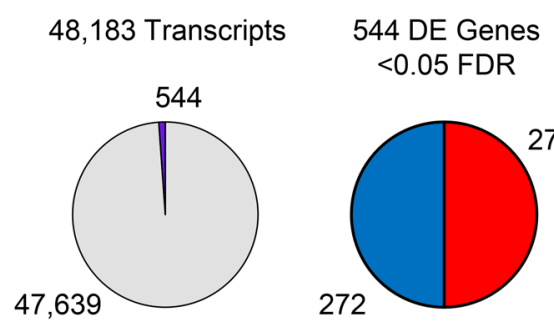

$\square$ Non-DE
$\square$ DE $<0.05$ FDR

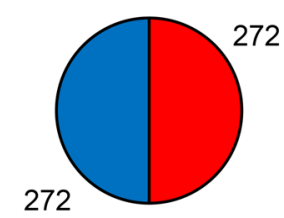

Sphk2+t+

- Sphk2-1

C

Top 24 DE Genes

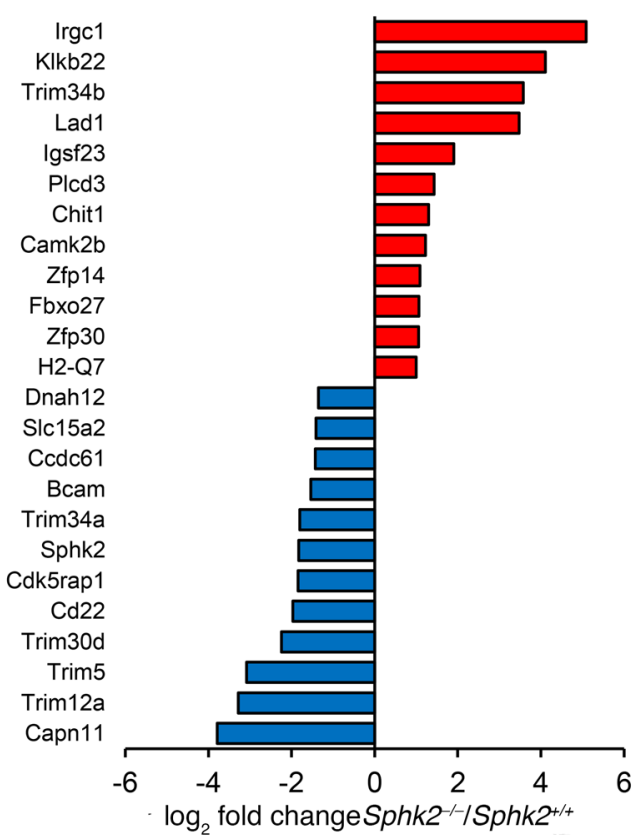

$\mathbf{E}$

TNF-a signaling via NFkB (Hall) DNA binding transcription factor activity (GO) Regulatory region nucleic acid binding (GO) Regulation of cell cycle (GO) Hypoxia (Hall) Response to endogeneous stimulus (GO) Intracellular receptor signaling pathway (GO) Chromatin binding (GO) Transcription factor binding (GO) Mitotic cell cycle (GO)

RNA pol II specific DNA binding transcription factor binding (GO) Negative regulation of apoptotic signaling pathway (GO) $\mathrm{T}$ cell differentiation (GO)

Molecular transducer activity (GO) Regulation of immune response (GO) Cell surface (GO) Secretion (GO) Immune effector process (GO) Leukocyte mediated immunity (GO)

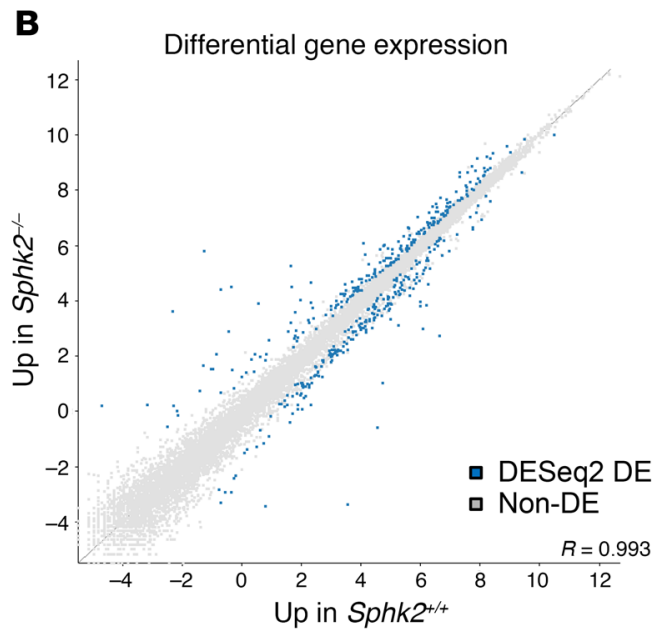

D

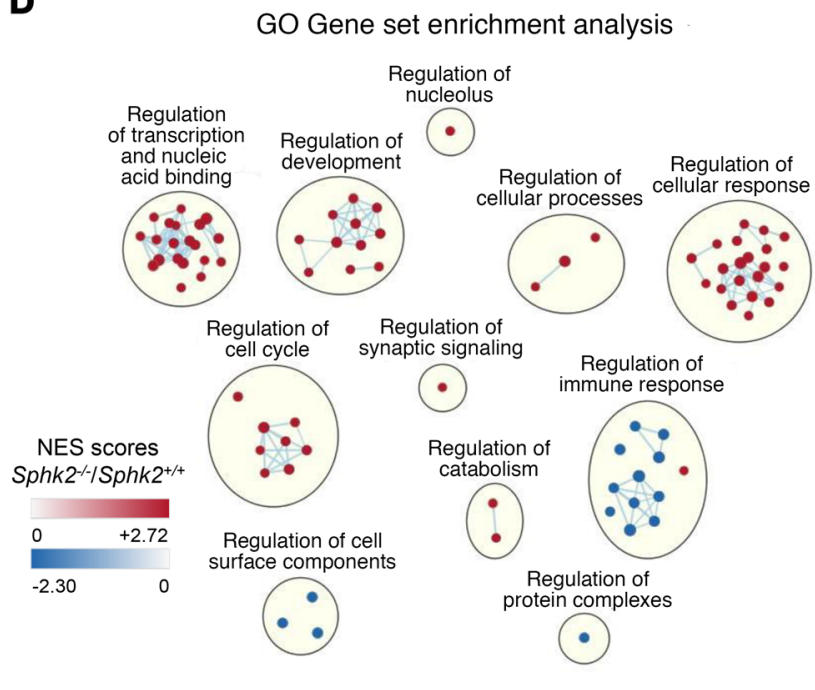

GSEA relevant gene sets

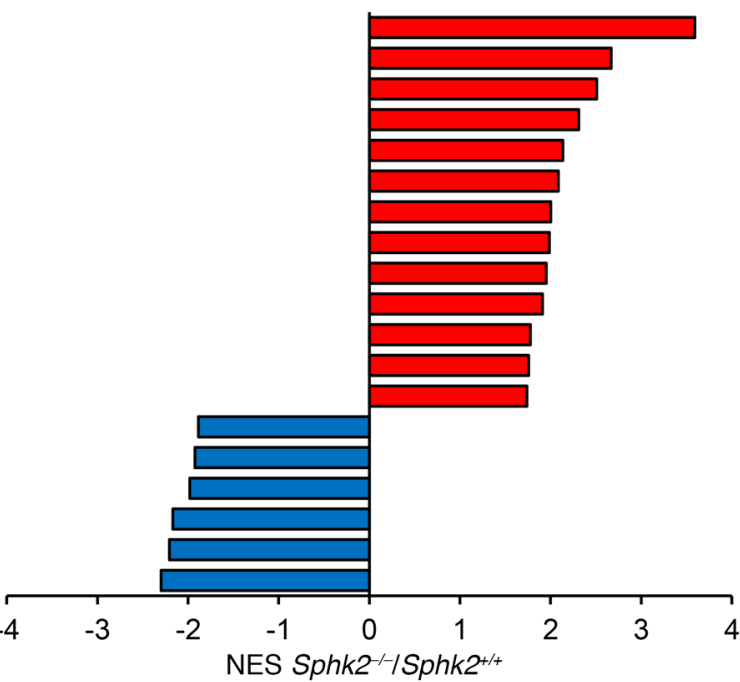


Figure 6. RNA-Seq analysis reveals changes in cellular transcription and cell cycle processes for SphK2-deficient virus-specific CD4 ${ }^{+}$T cells. (A-E) SphK2-sufficient or -deficient CD45.1 $1^{+} \mathrm{GP} 61 / \mathrm{CD} 4^{+} \mathrm{T}$ cells were adoptively transferred into WT mice, which were then infected with LCMV CI 13 ( $n=$ 3 mice/group). At $7 \mathrm{dpi}$, CD4+ $\mathrm{T}$ cells were column purified from the spleen and inguinal lymph node of mice and sorted for CD45.1+ expression by FACS. RNA was extracted from CD45.1 $1^{+}$cells and assessed for RNA-Seq. (A and B) DE analysis of genes with FDR of less than 0.05. (C) The log fold change for the top 12 genes that are upregulated or downregulated in the SphK2-deficient phenotype are shown. (D) Pathway analysis of $\mathrm{CO}$ gene sets with a significance FDR of less than 0.1 that correlates with the SphK2-deficient phenotype (red) or SphK2-sufficient phenotype (blue). Cene sets are grouped into clusters based on similar terminology, and lines connect gene sets that have equal to or greater than $75 \%$ identical genes. (E) Normalized enrichment scores (NES) for representative gene sets from the $\mathrm{GO}$ and Hall molecular signature databases that are correlated with the SphK2-deficient phenotype (positive values) or SphK2-sufficient phenotype (negative values) following GSEA.

naling are important for regulating kidney fibrosis in mice when the disease was induced by diverse treatments, including folic acid; however, the results seemed to be dependent on the treatment conditions (68-71). Our study suggests that SphK2 plays a vital role in attenuating host immune responses and the associated kidney disease following a virus infection. Therefore, this could be a very useful animal model for further investigation of the role of sphingolipids during kidney disease and what role host immunity has in the process.

Unlike LCMV Cl 13 infection, LCMV Arm, which causes acute infections, did not cause mortality in SphK2-deficient mice (Figure 1C). LCMV Arm infection still increased $\mathrm{CD} 4^{+} \mathrm{T}$ cell responses, but not $\mathrm{CD} 8^{+} \mathrm{T}$ cell expansion (Supplemental Figure 4). In support of this, LCMV Arm infection increased the expression of SphK2 and pSphK2 in $\mathrm{CD}_{4}{ }^{+} \mathrm{T}$ cells compared with uninfected $\mathrm{CD} 4^{+} \mathrm{T}$ cells (Figure $4 \mathrm{H}$ and Supplemental Figure 9). Therefore, the intrinsic function of SphK2 in diminishing $\mathrm{CD}^{+} \mathrm{T}$ cell proliferation is not limited to the immune-suppressive environment observed in LCMV Cl 13 infection. Perhaps transient or weak activation of SphK2 may commonly occur upon pathogenic infections to block massive proliferation of $\mathrm{T}$ cells and evade the ensuing immune pathologic injury. Whereas LCMV Arm is rapidly controlled by the potent $\mathrm{T}$ cell immunity, LCMV $\mathrm{Cl} 13$ effectively disseminates to diverse tissues and establishes viral persistence. This difference might have produced the distinct phenotypic outcomes, such as mortality from the infection of SphK2-deficient mice.

While transient inhibition of SphK2 in $\mathrm{CD}^{+} \mathrm{T}$ cells impairs the virus-induced immune-suppressive program, completely obstructing SphK2 function during infection leads to detrimental pathogenic conditions. This emphasizes the importance of balanced host immunity to control infections without injurious response (72). Importantly, this temporary inhibition of SphK2 using an orally bioavailable small molecule can eliminate LCMV Cl 13 in a persistently infected mouse (Figure 8). Virusmediated $\mathrm{T}$ cell evasion or suppression is typically observed during persistent viral infections in humans $(3,12,73)$. Therefore, we believe targeting of SphK2 may provide a promising route for developing a pharmaceutical intervention for eliciting protective $\mathrm{T}$ cell immunity against chronic viral infections that have a devastating impact on human health.

\section{Methods}

Additional details are provided in Supplemental Methods.

Mice. C57BL/6 (the Jackson Laboratory), C57BL/6-Sphk1-/, C57BL/6-Sphk2-/ $(74,75)$ (provided by Richard Proia, NIH, Bethesda, Maryland, USA, and Kelley Argraves and Lina Obeid, Medical University of South Carolina [MUSC], Charleston, South Carolina, USA), C57BL/6-Thy1.1 ${ }^{+} \mathrm{D}^{\mathrm{b}} \mathrm{GP}_{33-41}$ (Thy1.1 ${ }^{+}$GP33/CD8 ${ }^{+}$, P14) TCR Tg (76), and C57BL/6-CD45.1 $1^{+} \mathrm{I}-\mathrm{A}^{\mathrm{b}} \mathrm{GP}_{61-80}\left(\mathrm{CD} 45.1^{+}\right.$GP61/CD4 ${ }^{+}$, SMARTA) TCR Tg (77) mice (provided by Michael Oldstone, Scripps Research, La Jolla, California, USA) were used. $S p h k 2^{+/-}$mice were generated by one crossing of C57BL/6 and Sphk2/- mice. C57BL/6-Thy1.1 $1^{+}$ $\mathrm{D}^{\mathrm{b}} \mathrm{GP}_{33-41}$ Sphk2 $^{-/}\left(\right.$Sphk2 $^{-/}$Thy1.1 ${ }^{+}$GP33/CD8 $\left.{ }^{+}\right)$TCR Tg and C57BL/6-CD 45.1 $1^{+} \mathrm{I}^{-\mathrm{A}^{\mathrm{b}} \mathrm{GP}}{ }_{61-80}$ Sphk2 $^{-/}\left(\right.$Sphk2 $^{-/-} \mathrm{CD} 45.1^{+}$GP61/CD $\left.4^{+}\right)$ TCR Tg were established by crossing TCR Tg mice with Sphk2/- mice for at least 4 generations. Six to eight-week-old male or female mice were used; LCMV clearance studies used 6- to 8-week-old male C57BL/ 6 mice. Mice were bred and maintained in a closed breeding facility according to institutional guidelines.

Virus and infections. The Arm and $\mathrm{Cl} 13$ strains of LCMV were propagated on baby hamster kidney (BHK) cells $(52,76,78)$. LCMV titers were determined by plaque assay on Vero (African green monkey kidney) cells $(76,78)$. BHK and Vero cells and LCMV were initially provided by Michael Oldstone. Mice were infected by i.v. administration of $2 \times 10^{6}$ PFU of LCMV Cl 13 unless noted differently. For LCMV Arm survival experiments, mice were infected with $2 \times 10^{6}$ PFU of LCMV Arm by i.v. administration. To determine $\mathrm{T}$ cell responses to LCMV Arm, mice were infected by i.p. administration of $2 \times 10^{5}$ PFU LCMV Arm. Uninfected mice were used in all in vivo experiments as background controls.

Histology. Tissue samples were collected during the necropsy, fixed in $10 \%$ neutral buffered formalin, trimmed, processed by routine procedure, embedded in paraffin, sectioned to $4 \mu \mathrm{m}$ thickness, and captured on glass slides. The slides were stained with H\&E or PAS by using modified Schiff Reagent Solution (Thermo Fisher Scientific) for microscopic evaluation.

Lymphocyte isolation. Splenocyte suspensions were obtained by forcing spleens through a $40 \mu \mathrm{m}$ nylon mesh. Then cells were collected, red blood cells were lysed, and cells were used in downstream experiments. Cells were washed and used for flow cytometric analysis. Single cell suspensions of liver tissue were obtained by forcing tissue through nylon mesh. Lymphocytes were obtained by gradient centrifugation with Percoll (MilliporeSigma).

In vitro T cell proliferation assay. LCMV epitope GP61-specific CD $4^{+}$

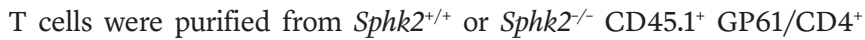
mice using EasySep $\mathrm{CD}^{+} \mathrm{T}$ cell enrichment negative selection reagents (Stem Cell Technologies) according to the manufacturer's protocol. Isolated cells $\left(5 \times 10^{6}\right)$ were stained with $5 \mu \mathrm{M}$ CFSE (Invitrogen) according to the manufacturer's protocol. BM-DCs were derived as described in the Supplemental Methods. BM-DCs were infected overnight with LCMV Cl 13 (MOI = 10) for 1 hour (76). Infected/treated BM-DCs were mixed with the isolated $\mathrm{CD} 4^{+} \mathrm{T}$ cells at a DC/T cell ratio of 1:10. After 5 days of incubation, the cells were harvested and the CFSE dilution was analyzed by flow cytometry.

$T$ cell depletion. $\mathrm{CD}^{+} \mathrm{T}$ cells were depleted using a single 150 $\mu$ g, i.p. dose of anti-CD4 antibody (GK1.5, purified functional grade, eBioscience) or isotype control at 1 day before LCMV infection. Depletion was assessed $7 \mathrm{dpi}$. $\mathrm{CD}^{+} \mathrm{T}$ cells were depleted using $250 \mu$ i.p. doses of anti-CD8 antibody (YTS 156 hybrid- 
A

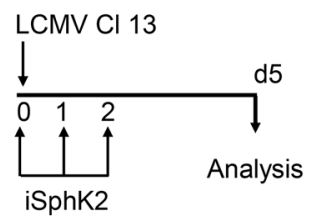

D

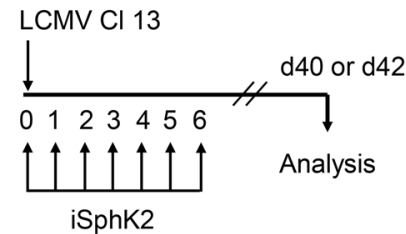

iSphK2
B

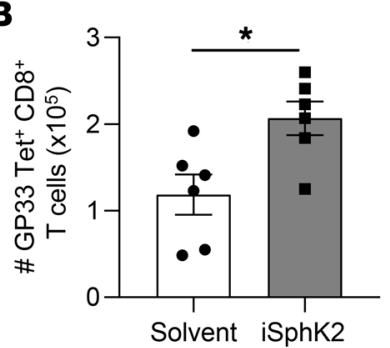

E
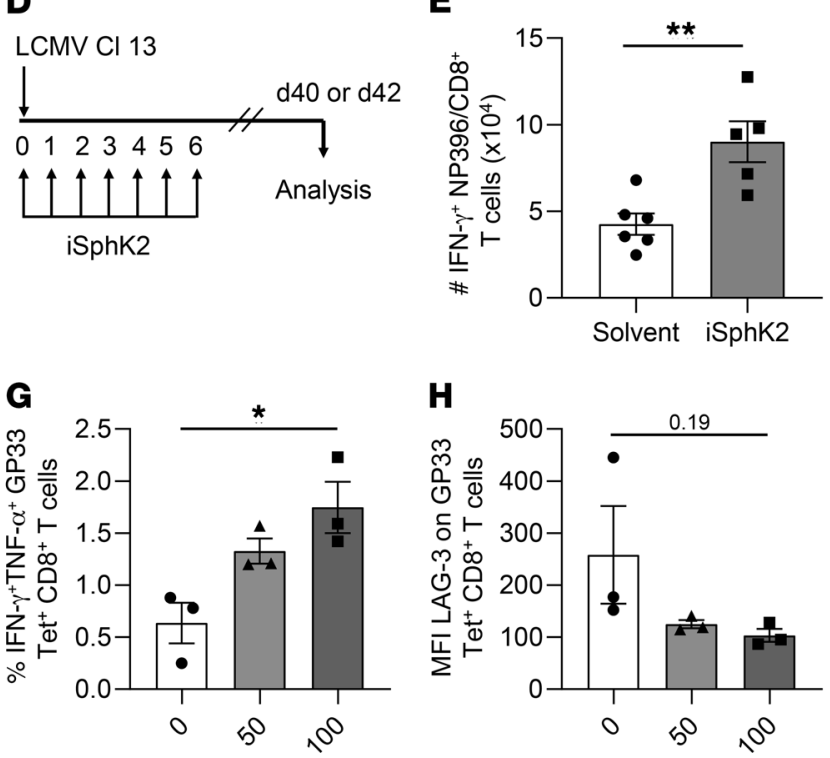

iSphK2 $(\mathrm{mg} / \mathrm{kg})$

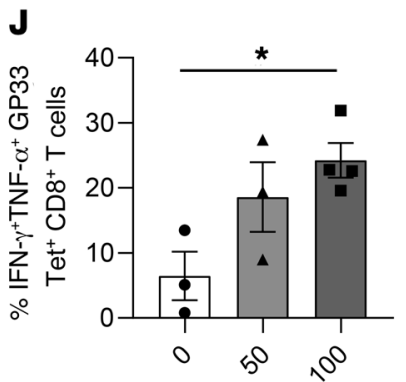

iSphK2 (mg/kg)
H

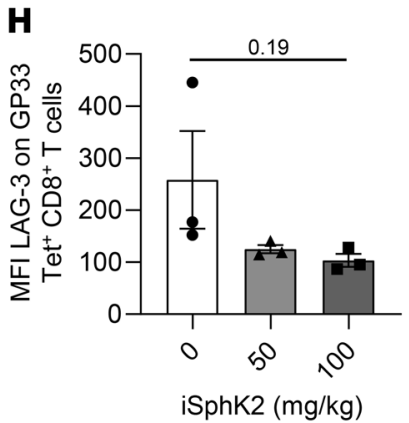

K

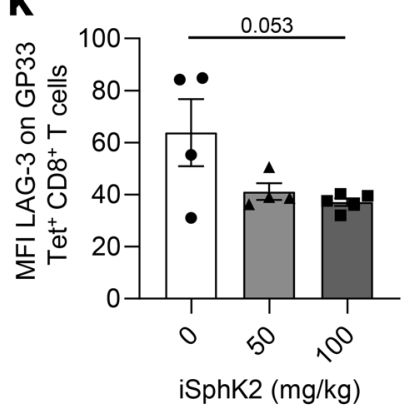

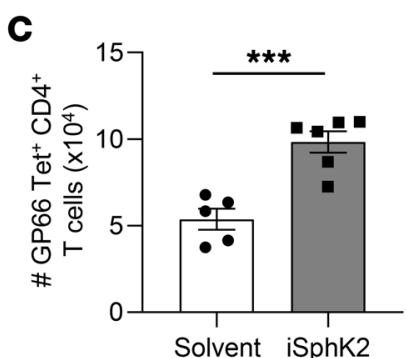

$\mathbf{F}$
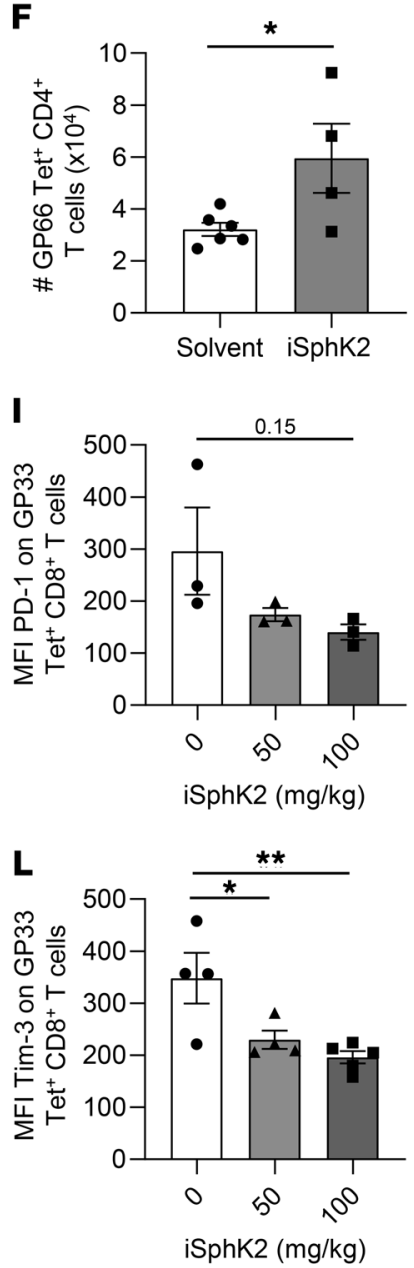

Figure 7. SphK2 inhibition enhances virus-specific $T$ cell responses. (A-C) LCMV CI 13-infected mice ( $n=5-6$ mice/group) were treated with 100

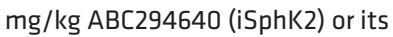
solvent by oral gavage each day from day 0 to $2 \mathrm{dpi}$. At $5 \mathrm{dpi}$, the numbers of GP33 $\mathrm{Tet}^{+}{ }^{+} \mathrm{CD}^{+} \mathrm{T}$ cells (B) or GP66 $\mathrm{Tet}^{+} \mathrm{CD} 4^{+} \mathrm{T}$ cells $(\mathbf{C})$ in the spleen were assessed by flow cytometry. (D-F) LCMV Cl 13-infected mice ( $n$ = 4-6 mice/group) were treated for 7 days with $100 \mathrm{mg} / \mathrm{kg}$ iSphK2 from day 0 to 6 dpi. At $42 \mathrm{dpi}$, the number of IFN- $\gamma$-producing NP396/CD8 ${ }^{+}$(E) and $\mathrm{CP} 66 \mathrm{Tet}^{+} \mathrm{CD}^{+}$(F) T cells were determined in the spleen. (G-L) LCMV Cl 13-infected mice ( $n=3-5$ mice) group) were treated with solvent (0 $\mathrm{mg} / \mathrm{kg}$ ), $50 \mathrm{mg} / \mathrm{kg}$, or $100 \mathrm{mg} / \mathrm{kg}$ iSphK2. At $40 \mathrm{dpi}$, spleen (G-I) and liver $(\mathbf{J}-\mathbf{L})$ tissues were analyzed by flow cytometry for the percentage of IFN- $\gamma^{+}$TNF- $\alpha{ }^{+}$CP33 Tet $^{+}$CD8 ${ }^{+}$T cells (G and $\mathbf{J}$ ), and the MFI of LAG-3 ( $\mathbf{H}$ and K), PD-1 (I), and Tim-3 (L) on GP33 Tet CD8 ${ }^{+}$T cells. ${ }^{*} P \leq 0.05 ;{ }^{* *} P \leq 0.01$; ${ }^{* * *} P \leq 0.001$, bidirectional, unpaired Student's $t$ test (B, C, E, and F), 1-way ANOVA with Tukey's post hoc test (G-L). Data are representative of 2-3 independent experiments. oma supernatant which was provided by Helen Mullen, University of Missouri-Columbia) administered 1 day before and 7 dpi (79). Depletion was assessed $7 \mathrm{dpi}$.

Adoptive transfer of $C D 4^{+}$and $C D 8^{+} T$ cells. For adoptive T cell transfer experiments, splenocytes were prepared as above. CD 45.1 $1^{+}$GP61/CD $4^{+}$ and Thy1.1 ${ }^{+}$GP33/CD8 ${ }^{+} \mathrm{T}$ cells were isolated using EasySep (Stem Cell Technologies) or MojoSort (BioLegend) $\mathrm{CD}^{+}$and $\mathrm{CD} 8^{+} \mathrm{T}$ cell enrichment negative selection reagents according to the manufacturer's instructions. Purity was assessed by flow cytometry before adoptive transfer of 1 $\times 10^{4} \mathrm{CD}^{+}$or $1 \times 10^{4} \mathrm{CD}^{+} \mathrm{T}$ cells into WT mice by i.v. injection.

Flow cytometric analysis. Antibodies used in this study are listed in the Supplemental Methods. For staining of immune cells in kidney, Ghost Dye (Tonbo Biosciences) was used for detecting live cells. LCMV GP33-specific $\mathrm{CD}^{+} \mathrm{T}$ cells were identified using fluorochrome-linked $\mathrm{GP}_{33-41}$ tetramers, and LCMV GP $66-77^{-}$-specific $\mathrm{CD}^{+} \mathrm{T}$ cells were iden- tified using fluorochrome-linked GP66 tetramers (80), which were provided by the NIH Tetramer Core Facility (Emory University, Atlanta, Georgia, USA). For intracellular cytokine staining (52, 76, 78, 81), lymphocytes were cultured in the presence of $4 \mu \mathrm{g} / \mathrm{mL}$ of brefeldin A (MilliporeSigma) and $1 \mu \mathrm{g} / \mathrm{mL}$ GP33 (KAVYNFATC), NP396 (FQPQNGQFI), or GP276 (SGVENPGGYCL), or $5 \mu \mathrm{g}$ GP61 (GLNGPDIYKGVYQFKSVEFD) peptide for 5.5 hours and then fixed, permeabilized, and stained with indicated antibodies. Data were collected on a CyAn ADP Flow Cytometer (Beckman Coulter) or LSRFortessa X-20 (BD Biosciences) and analyzed with FlowJo (Tree Star) software.

Determination of virus titers. The serum, lung, kidney, or spleen tissues were harvested from infected and uninfected mice at the time points indicated. Tissues were homogenized using a BeadBeater with $1.0 \mathrm{~mm}$ diameter Zirconia/Silica beads (BioSpec Products). LCMV titers were determined by plaque assay on Vero cells. In multidose 

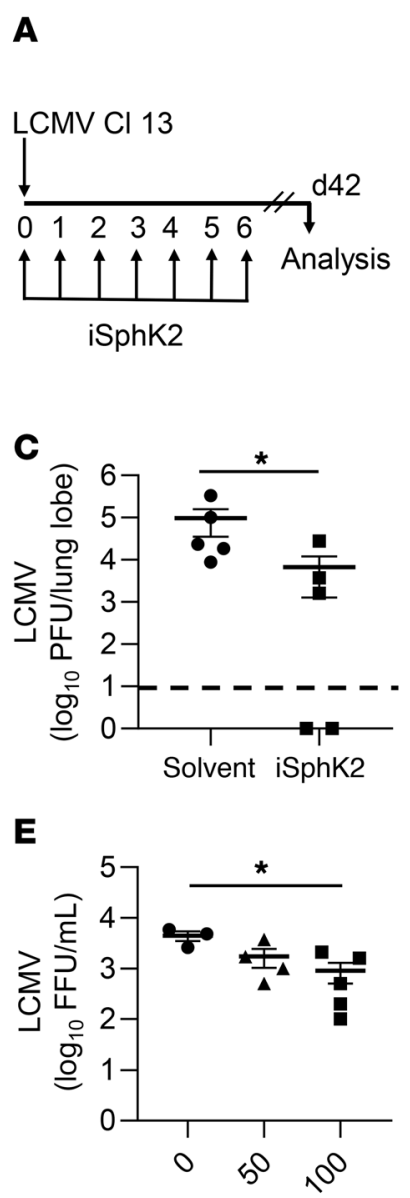

iSphK2 $(\mathrm{mg} / \mathrm{kg})$
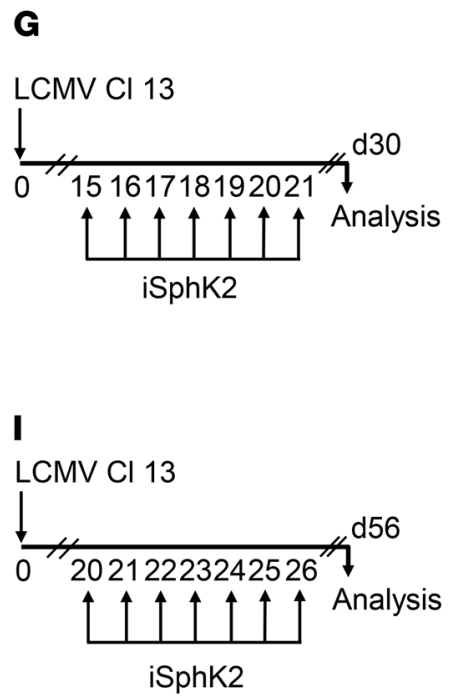
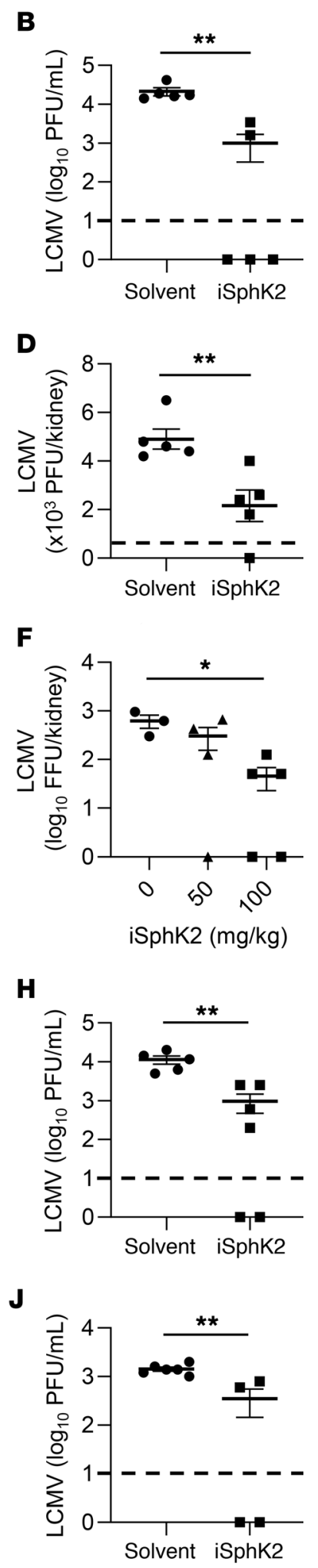

studies with iSphK2, viral titers were determined by focus-forming assay on Vero cells as described previously (82). A summation of the procedure is provided in Supplemental Methods.

Western blot analysis. Western blots were prepared as described in Supplemental Methods. Densitometry analysis of Western blots was done using Image Studio Lite (LI-COR) or ImageJ.
Figure 8. Inhibition of SphK2 results in accelerated clearance of persistent LCMV infection. (A-D) WT mice ( $n=5$ mice/group) were infected with LCMV CI 13 and treated daily for 7 days with $100 \mathrm{mg} / \mathrm{kg}$ iSphK2 or solvent by oral gavage from day 0 . At $42 \mathrm{dpi}$, LCMV titers were determined in the serum (B), lungs (C), and kidneys (D) of infected mice by plaque assay. ( $\mathbf{E}$ and $\mathbf{F}$ ) LCMV CI 13-infected mice ( $n=3-5$ mice/group) were treated with solvent $(0 \mathrm{mg} / \mathrm{kg})$ or $50 \mathrm{mg} / \mathrm{kg}$ or $100 \mathrm{mg} / \mathrm{kg}$ iSphK2 daily for 7 days. (E) LCMV Cl 13 viral titers (focus forming units [FFU]) were assayed in serum at $30 \mathrm{dpi}$. (F) At $40 \mathrm{dpi}$, viral titers (FFU) in the kidney were assessed. ( $\mathbf{G}$ and $\mathbf{H}$ ) LCMV CI 13-infected mice ( $n=5-6$ mice/group) were treated daily with iSphK2 beginning on 15 dpi for 7 days. At $30 \mathrm{dpi}$, LCMV titers were determined in the serum (H). (I and J) LCMV CI 13-infected mice ( $n=4-6$ mice/group) were treated with iSphK2 or solvent from 20 to $26 \mathrm{dpi}$. At $56 \mathrm{dpi}$, LCMV titers were determined in the serum (J). ${ }^{*} P$ $\leq 0.05$; ${ }^{* *} P \leq 0.01$, Mann-Whitney nonparametric test (B-D, $\mathbf{H}$, and $\left.\mathbf{J}\right)$, Kruskal-Wallis nonparametric test with Dunn's test (E and $\mathbf{F}$ ). Data are representative of 2-3 independent experiments. The limits of detection are depicted as dotted lines.

RNA-Seq and bioinformatic analysis. Sphk2 $2^{+/+}$or Sphk2 $2^{-1-}$ CD45.1 ${ }^{+}$GP61/CD4 ${ }^{+} \mathrm{T}$ cells were isolated and transferred into WT mice 1 day before LCMV Cl 13 infection as above. At 7 dpi, spleens and inguinal lymph nodes were harvested from infected mice and forced through nylon mesh. $\mathrm{CD}^{+} \mathrm{T}$ cells were subsequently purified via EasySep positive selection (Stem Cell Technologies) according to the manufacturer's protocol. CD $45.1^{+}$cells were then sorted from $\mathrm{CD} 4^{+}$cells using the MoFlo XDP (Beckman Coulter, University of Missouri Cell and Immunobiology Core). RNA was isolated from CD $45.1^{+} \mathrm{CD} 4^{+}$cells using the Aurum Total RNA Mini Kit (Bio-Rad). mRNA was sequenced with an average of 55 million single-end reads (Cofactor Genomics). Fastq files from each replicate were uploaded to Cyverse Discovery Environment via iDrop (iRODS) (83). The quality of reads was checked with FastQC (version 0.11.5, Upendra Kumar Devisetty, Cyverse) (84). Reads were aligned to the Mus musculus GRCm38.p6 release 99 primary genome assembly (Ensembl) using the HiSat2 sequence aligner (version 2.1, Kapeel Chougule, Cyverse) (84-87). Indexed files were downloaded, and raw transcript counts were generated in SeqMonk (Babraham Institute). SeqMonk was used to generate the differential expression (DE) scatter plot. Transcripts were compared for DE using DESeq2 in GenePattern (Broad Institute) $(88,89)$. The normalized expression values of $\mathrm{DE}$ genes with a $q$ value (FDR) of less than 0.05 were used in downstream analyses. Transcripts were renamed using mouse genome informatics (MGI) naming identifications (Ensembl and MGI) $(87,90)$. GSEA (Broad Institute) was conducted using the GO and Hall molecular signature databases (version 7.0) (91-94). Gene sets from the GO database with a $q$ value of less than 0.1 were mapped using EnrichmentMap and clustered based on gene set names using AutoAnnotate in Cytoscape (95-97). Gene sets with greater than 75\% gene similarity are connected with lines. Heatmaps were constructed based on calculated $Z$ scores using Morpheus (Broad Institute) (98). These data are available in the GEO database (GSE155030).

Biochemical analysis of serum. Blood was collected from Sphk2-or WT mice on 15 or 17 dpi (depending on the severity of disease in $S p h k 2^{-/-}$mice). Serum was isolated from total blood via centrifugation and stored at $-80^{\circ} \mathrm{C}$ until used. A complete clinical chemistry profile analysis of the serum was performed on an automated clinical chemistry analyzer (AU680, Beckman Coulter) by Comparative Clinical 
Pathology Services LLC (99). Serum sodium, chloride, and potassium were measured as above employing ion-specific electrodes.

$E B$ analysis. Prior to sacrifice, mice were anesthetized and given i.v. $200 \mu \mathrm{L}$ of a $0.5 \%$ solution of EB dye (Alfa Aesar) in PBS $(44,100)$. Mice were monitored for 30 minutes and then euthanized via cervical dislocation. Tissues were collected and dried for approximately 72 hours. Wet and dry weights were recorded. Subsequently, $500 \mu \mathrm{L}$ formamide (Alfa Aesar) was added to dry tissues in microcentrifuge tubes. Samples were incubated in a $55^{\circ} \mathrm{C}$ water bath for 48 hours, 200 $\mu \mathrm{L}$ from each sample was added to a 96-well plate, and absorbance at $620 \mathrm{~nm}$ compared with a formamide blank was measured on an Epoch Microplate Spectrophotometer (BioTek Instruments).

SphK2 inhibitor. SphK2 was inhibited using ABC294640 (iSphK2) (MedKoo). For administration, the inhibitor was formulated to a dose of $10 \mathrm{mg} / \mathrm{mL}$ in $50 \%$ PEG, $5 \%$ DMSO. Mice were given a $50-100 \mathrm{mg} /$ $\mathrm{kg}$ dose by intragastric gavage (50). The solvent is equivalent to a solution of PEG and DMSO without the inhibitor.

Statistics. All error bars represent mean \pm SEM, and averages were compared using a bidirectional (2-tailed), unpaired Student's $t$ test $(52,76,78,101)$ unless otherwise indicated. In the case of different sample sizes, an unequal variances $t$ test was employed. For pairwise comparisons, 1-way ANOVA was performed followed by Tukey's post hoc test or Dunnett's test. For virus titers, Mann-Whitney $U$ test, or for pairwise comparisons, a Kruskal-Wallis test with Dunn's test was used to account for nonparametric viral clearance. Graph constructions and statistical analyses were performed using Prism 8 (GraphPad). A P value less than or equal to 0.05 was considered significant for these tests. For RNA-Seq data, a $q$ value (FDR) of less than 0.05 was used. For GSEA pathway analyses, a $q$ value (FDR) of less than 0.1 was used. Mantel-Cox log-rank tests were performed for survival curves in Prism (GraphPad) (39, 102). Data are representative of 2-3 independent experimental repetitions.

Study approval. The animal studies presented here were approved by the Animal Care and Use Committee of the University of MissouriColumbia and Jeonbuk National University (CBNU 2019-013).

\section{Author contributions}

CJS, CJP, and YJS contributed to experimental designs, conduction of experiments, data analysis, and manuscript preparation. DYK performed histological studies and analysis. CX, JJW, and MV provided assistance with experiments and feedback on experimental design. RN offered guidance and analysis of kidney disease and biochemical analysis of serum. YJS, YBC, KWK, and SML participated in the multidose inhibitor studies. $\mathrm{BH}$ was involved in conception of the research, experimental design, data analysis, and manuscript preparation.

\section{Acknowledgments}

We thank Richard Proia (NIH/National Institute of Diabetes and Digestive and Kidney Diseases) and Kelley Argraves and Lina Obeid (MUSC) for the provision of $S p h k 1^{-/-}$and $S p h k 2^{---}$mice. We also thank Michael Oldstone (Scripps Research) for providing us with the GP33 and GP61 TCR Tg mice. GP33 and GP66 tetramers were provided by the NIH Tetramer Core Facility (Emory University). We thank Helen Mullen (University of Missouri) for providing the $\mathrm{CD}^{+} \mathrm{T}$ cell-depleting monoclonal antibody. Finally, we thank Daniel Jackson (University of Missouri Cell and Immunobiology Core) for help with cell sorting. CJS and JJW were supported by the Life Sciences Fellowship at the University of Missouri-Columbia. This study was supported by NIH/National Institute of Allergy and Infectious Diseases (NIH/NIAID) grant R21AI127404 (to BH) and National Research Foundation of Korea (NRF) grants funded by the Korean government (MSIT) (NRF2018R1A5A1025077) (to YJS).

Address correspondence to: Bumsuk Hahm, University of Missouri-Columbia, Medical Science Building M331, One Hospital Dr., Columbia, Missouri 65212, USA. Phone: 573.884.8838; Email: hahmb@health.missouri.edu. Or to: Young-Jin Seo, Chung-Ang University, 84 Heukseok-ro, Dongjak-gu, Seoul 06974, Korea. Phone: 82.2.820.5925; Email: yjseo@cau.ac.kr.
1. Liu B, Woltman AM, Janssen HLA, Boonstra A. Modulation of dendritic cell function by persistent viruses. J Leukoc Biol. 2009;85(2):205-214.

2. Steinman RM, et al. The interaction of immunodeficiency viruses with dendritic cells. In: Steinkasserer A, et al., eds. Dendritic Cells and Virus Infection. Current Topics in Microbiology and Immunology, 276. Springer;2003:1-30.

3. Ng CT, Snell LM, Brooks DG, Oldstone MBA. Networking at the level of host immunity: immune cell interactions during persistent viral infections. Cell Host Microbe. 2013;13(6):652-664.

4. Barber DL, et al. Restoring function in exhausted CD8 T cells during chronic viral infection. Nature. 2006;439(7077):682-687.

5. Zajac AJ, et al. Viral immune evasion due to persistence of activated $\mathrm{T}$ cells without effector function. J Exp Med. 1998;188(12):2205-2213.

6. Amman BR, et al. Pet rodents and fatal lymphocytic choriomeningitis in transplant patients. Emerging Infect Dis. 2007;13(5):719-725.

7. Gregg MB. Recent outbreaks of lymphocytic choriomeningitis in the United States of America. Bull World Health Organ. 1975;52(4-6):549-553.
8. Ahmed R, Salmi A, Butler LD, Chiller JM, Oldstone MB. Selection of genetic variants of lymphocytic choriomeningitis virus in spleens of persistently infected mice. Role in suppression of cytotoxic T lymphocyte response and viral persistence. JExp Med. 1984;160(2):521-540.

9. Sevilla N, Kunz S, McGavern D, Oldstone MBA. Infection of dendritic cells by lymphocytic choriomeningitis virus. In: Steinkasserer A, ed. Dendritic Cells and Virus Infection. Current Topics in Microbiology and Immunology, 276. Springer;2003:125-144.

10. Borrow P, Evans CF, Oldstone MB. Virus-induced immunosuppression: immune system-mediated destruction of virus-infected dendritic cells results in generalized immune suppression. JVirol. 1995;69(2):1059-1070.

11. Gallimore A, et al. Induction and exhaustion of lymphocytic choriomeningitis virus-specific cytotoxic T lymphocytes visualized using soluble tetrameric major histocompatibility complex class I-peptide complexes. J Exp Med. 1998;187(9):1383-1393.

12. Wherry EJ, et al. Molecular signature of CD8+
T cell exhaustion during chronic viral infection. Immunity. 2007;27(4):670-684.

13. Ejrnaes M, et al. Resolution of a chronic viral infection after interleukin-10 receptor blockade. J Exp Med. 2006;203(11):2461-2472.

14. Brooks DG, Ha SJ, Elsaesser H, Sharpe AH, Freeman GJ, Oldstone MB. IL-10 and PD-L1 operate through distinct pathways to suppress T-cell activity during persistent viral infection. Proc Natl Acad Sci U S A. 2008;105(51):20428-20433.

15. Teijaro JR, et al. Persistent LCMV infection is controlled by blockade of type I interferon signaling. Science. 2013;340(6129):207-211.

16. Wilson EB, et al. Blockade of chronic type I interferon signaling to control persistent LCMV infection. Science. 2013;340(6129):202-207.

17. Penaloza-MacMaster $P$, et al. Interplay between regulatory T cells and $\mathrm{PD}-1$ in modulating $\mathrm{T}$ cell exhaustion and viral control during chronic LCMV infection. JExp Med. 2014;211(9):1905-1918.

18. Vezys, $\mathrm{V}$ et al. 4-1BB signaling synergizes with programmed death ligand 1 blockade to augment CD8 T cell responses during chronic viral infection. J Immunol. 2011;187(4):1634-1642. 
19. Li C, Xu X, Wei B. PD-1 and CTLA-4 mediated inhibitory signaling for $\mathrm{T}$ cell exhaustion during chronic viral infections. J Clin Cell Immunol. 2012;S12:010.

20. Matloubian M, Kolhekar SR, Somasundaram T, Ahmed R. Molecular determinants of macrophage tropism and viral persistence: importance of single amino acid changes in the polymerase and glycoprotein of lymphocytic choriomeningitis virus. J Virol. 1993;67(12):7340-7349.

21. Battegay M, et al. Enhanced establishment of a virus carrier state in adult CD4+ T-cell-deficient mice. J Virol. 1994;68(7):4700-4704.

22. Smyk-Pearson $S$, et al. Spontaneous recovery in acute human hepatitis $\mathrm{C}$ virus infection: functional T-cell thresholds and relative importance of CD4 help. J Virol. 2008;82(4):1827-1837.

23. Grakoui A, et al. HCV persistence and immune evasion in the absence of memory $\mathrm{T}$ cell help. Science. 2003;302(5645):659-62.

24. Rosen H, Goetzl EJ. Sphingosine 1-phosphate and its receptors: an autocrine and paracrine network. Nat Rev Immunol. 2005;5(7):560-570.

25. Cyster JG. Chemokines, sphingosine-1-phosphate, and cell migration in secondary lymphoid organs. Annu Rev Immunol. 2005;23:127-159.

26. Takabe K, Paugh SW, Milstien S, Spiegel S. "Inside-out" signaling of sphingosine-1phosphate: therapeutic targets. Pharmacol Rev. 2008;60(2):181-195.

27. Samy ET et al. Cutting edge: modulation of intestinal autoimmunity and IL-2 signaling by sphingosine kinase 2 independent of sphingosine 1-phosphate. J Immunol. 2007;179(9):5644-5648.

28. Yoshimoto T, et al. Positive Modulation of IL-12 signaling by sphingosine kinase 2 associating with the IL-12 receptor $\beta 1$ cytoplasmic region. JImmunol. 2003;171(3):1352-1359.

29. Pitson SM. Regulation of sphingosine kinase and sphingolipid signaling. Trends Biochem Sci. 2011;36(2):97-107.

30. Alvarez SE, et al. Sphingosine-1-phosphate is a missing cofactor for the E3 ubiquitin ligase TRAF2. Nature. 2010;465(7301):1084-1088.

31. Lai W-Q, et al. Anti-inflammatory effects of sphingosine kinase modulation in inflammatory arthritis. J Immunol. 2008;181(11):8010-8017.

32. Hait NC, et al. Regulation of histone acetylation in the nucleus by sphingosine-1-phosphate. Science. 2009;325(5945):1254-1257.

33. Seo Y-J, Blake C, Alexander S, Hahm B. Sphingosine 1-phosphate-metabolizing enzymes control influenza virus propagation and viral cytopathogenicity. J Virol. 2010;84(16):8124-8131.

34. Seo Y-J, et al. Sphingosine kinase 1 serves as a pro-viral factor by regulating viral RNA Synthesis and nuclear export of viral ribonucleoprotein complex upon influenza virus infection. PLoS One. 2013;8(8):e75005.

35. Vijayan M, et al. Sphingosine kinase 1 regulates measles virus replication. Virology. 2014;450451(6):55-63.

36. Machesky NJ, et al. Human cytomegalovirus regulates bioactive sphingolipids. J Biol Chem. 2008;283(38):26148-26160.

37. Reid SP, et al. Sphingosine kinase 2 is a chikungunya virus host factor co-localized with the viral replication complex. Emerg Microbes Infect. 2015;4(10):e61.

38. Dai L, et al. Sphingosine kinase-2 maintains viral latency and survival for KSHV-infected endothelial cells. PLoS One. 2014;9(7):e102314.

39. Xia C, Seo YJ, Studstill CJ, Vijayan M, Wolf JJ, Hahm B. Transient inhibition of sphingosine kinases confers protection to influenza A virus infected mice. Antiviral Res. 2018;158:171-177.

40. Barra G, et al. Sphingosine kinases promote IL-17 expression in human T lymphocytes. Sci Rep. 2018;8(1):13233.

41. Stamm A, Valentine L, Potts R, PremenkoLanier M. An intermediate dose of LCMV clone 13 causes prolonged morbidity that is maintained by CD4+ T cells. Virology. 2012;425(2):122-132.

42. Sethi S, et al. Mayo Clinic/Renal Pathology Society consensus report on pathologic classification, diagnosis, and reporting of GN. J Am Soc Nephrol. 2016;27(5):1278-1287.

43. Madaio MP, Harrington JT. The diagnosis of glomerular diseases. Arch Intern Med. 2001;161(1):25-34.

44. Frebel H, et al. Programmed death 1 protects from fatal circulatory failure during systemic virus infection of mice. J Exp Med. 2012;209(13):2485-2499.

45. Waggoner SN, Cornberg M, Selin LK, Welsh RM. Natural killer cells act as rheostats modulating antiviral T cells. Nature. 2012;481(7381):394-398

46. Xie JH, et al. Sphingosine-1-phosphate receptor agonism impairs the efficiency of the local immune response by altering trafficking of naive and antigen-activated CD4 + T cells. J Immunol. 2003;170(7):3662-3670.

47. Brooks DG, Teyton L, Oldstone MBA, McGavern DB. Intrinsic functional dysregulation of CD4 $T$ cells occurs rapidly following persistent viral infection. J Virol. 2005;79(16):10514-10527.

48. Zajac AJ, Quinn DG, Cohen PL, Frelinger JA. Fas-dependent CD4+ cytotoxic T-cell-mediated pathogenesis during virus infection. Proc Natl Acad Sci U S A. 1996;93(25):14730-14735.

49. Nagata S, Golstein P. The Fas death factor. Science. 1995;267(5203):1449-1456.

50. French KJ, et al. Pharmacology and antitumor activity of ABC294640, a selective inhibitor of sphingosine kinase-2. JPharmacol Exp Ther. 2010;333(1):129-139.

51. Orr Gandy KA, Obeid LM. Targeting the sphingosine kinase/sphingosine 1-phosphate pathway in disease: review of sphingosine kinase inhibitors. Biochim Biophys Acta. 2013;1831(1):157-166.

52. Hahm B, Trifilo MJ, Zuniga EI, Oldstone MBA. Viruses evade the immune system through type I interferon-mediated STAT2-dependent, but STAT1-independent, signaling. Immunity. 2005;22(2):247-257.

53. Maceyka M, et al. SphK1 and SphK2, sphingosine kinase isoenzymes with opposing functions in sphingolipid metabolism. J Biol Chem. 2005;280(44):37118-37129.

54. Alemany R, van Koppen CJ, Danneberg K, Ter Braak M, Meyer Zu Heringdorf D. Regulation and functional roles of sphingosine kinases. Naunyn Schmiedebergs Arch Pharmacol. 2007;374(5-6):413-428.

55. Xia P, et al. Sphingosine kinase interacts with TRAF2 and dissects tumor necrosis factor- $\alpha$ signaling. J Biol Chem. 2002;277(10):7996-8003.

56. Pchejetski $D$, et al. The involvement of sphingosine kinase 1 in LPS-induced Toll-like receptor 4-mediated accumulation of HIF-1 $\alpha$ protein, activation of ASK1 and production of the pro-inflammatory cytokine IL-6. Immunol Cell Biol. 2011;89(2):268-274.

57. Snider AJ, et al. A role for sphingosine kinase 1 in dextran sulfate sodium-induced colitis. FASEB J. 2009;23(1):143-152.

58. Lai W-Q, et al. Distinct roles of sphingosine kinase 1 and 2 in murine collagen-induced arthritis. JImmunol. 2009;183(3):2097-2103.

59. Xu T, Li L, Huang C, Peng Y, Li J. Sphingosine kinase 2: a controversial role in arthritis. Rheumatol Int. 2014;34(7):1015-1016.

60. Walsh $\mathrm{CM}$, et al. Immune function in mice lacking the perforin gene. Proc Natl Acad Sci U S A. 1994;91(23):10854-10858.

61. Storm P, Bartholdy C, Sørensen MR, Christensen JP, Thomsen AR. Perforin-deficient CD8+ T cells mediate fatal lymphocytic choriomeningitis despite impaired cytokine production. J Virol. 2006;80(3):1222-1230.

62. Matloubian M, et al. A role for perforin in downregulating T-cell responses during chronic viral infection. J Virol. 1999;73(3):2527-2536.

63. Kang SS, McGavern DB. Lymphocytic choriomeningitis infection of the central nervous system. Front Biosci. 2008;13(13):4529-4543.

64. Vijayan M, Hahm B. Influenza viral manipulation of sphingolipid metabolism and signaling to modulate host defense system. Scientifica (Cairo). 2014;2014:793815.

65. Wolf JJ, Studstill CJ, Hahm B. Emerging connections of S1P-metabolizing enzymes with host defense and immunity during virus infections. Viruses. 2019;11(12):1097.

66. Lovric S, et al. Mutations in sphingosine-1phosphate lyase cause nephrosis with ichthyosis and adrenal insufficiency. JClin Invest. 2017;127(3):912-928.

67. Prasad R, et al. Sphingosine-1-phosphate lyase mutations cause primary adrenal insufficiency and steroid-resistant nephrotic syndrome. JClin Invest. 2017;127(3):942-953.

68. Snider AJ, Ruiz P, Obeid LM, Oates JC. Inhibition of sphingosine kinase- 2 in a murine model of lupus nephritis. PLoS One. 2013;8(1):e53521.

69. Bajwa A, et al. Sphingosine kinase 2 deficiency attenuates kidney fibrosis via IFN- $\gamma$. J Am Soc Nephrol. 2017;28(4):1145-1161.

70. Park SW, Kim M, Kim M, D’Agati VD, Lee HT. Sphingosine kinase 1 protects against renal ischemia-reperfusion injury in mice by sphingosine-1-phosphate1 receptor activation. Kidney Int. 2011;80(12):1315-1327.

71. Schwalm S, Pfeilschifter J, Huwiler A. Targeting the sphingosine kinase/sphingosine 1-phosphate pathway to treat chronic inflammatory kidney diseases. Basic Clin Pharmacol Toxicol. 2014;114(1):44-49.

72. Moseman EA, McGavern DB. The great balancing act: regulation and fate of antiviral T-cell interactions. Immunol Rev. 2013;255(1):110-124.

73. Yi JS, Cox MA, Zajac AJ. T-cell exhaustion: characteristics, causes and conversion. Immunology. 2010;129(4):474-481.

74. Allende ML, et al. Mice deficient in sphingosine 
kinase 1 are rendered lymphopenic by FTY720. J Biol Chem. 2004;279(50):52487-52492.

75. Don AS, et al. Essential requirement for sphingosine kinase 2 in a sphingolipid apoptosis pathway activated by FTY720 analogues. J Biol Chem. 2007;282(21):15833-15842.

76. Pritzl CJ, et al. A ceramide analogue stimulates dendritic cells to promote t cell responses upon virus infections. JImmunol. 2015;194(9):4339-4349.

77. Fahey LM, et al. Viral persistence redirects CD4 $\mathrm{T}$ cell differentiation toward $\mathrm{T}$ follicular helper cells. JExp Med. 2011;208(5):987-999.

78. Seo YJ, Hahm B. Sphingosine analog AAL-R promotes activation of LCMV-infected dendritic cells. Viral Immunol. 2014;27(2):82-86.

79. Wei Y, Chen K, Sharp GC, Yagita H, BraleyMullen H. Expression and regulation of Fas and Fas ligand on thyrocytes and infiltrating cells during induction and resolution of granulomatous experimental autoimmune thyroiditis. J Immunol. 2001;167(11):6678-6686.

80. Jeannet G, Boudousquié C, Gardiol N, Kang J, Huelsken J, Held W. Essential role of the Wnt pathway effector Tcf-1 for the establishment of functional CD8 T cell memory. Proc Natl Acad Sci US A. 2010;107(21):9777-9782.

81. Hassett DE, Zhang J, Slifka M, Whitton JL. Immune responses following neonatal DNA vaccination are long-lived, abundant, and qualitatively similar to those induced by conventional immunization. J Virol. 2000;74(6):2620-2627.

82. Battegay M, et al. Quantification of lymphocytic choriomeningitis virus with an immunological focus assay in 24- or 96-well plates. J Virol.
1991;33(1-2):191-198.

83. Rajasekar, A et al. The integrated Rule-Oriented Data System (iRODS 4.0) Microservice Workbook. Renaissance Computing Institute; 2015.

84. Merchant N, et al. The iPlant Collaborative: cyberinfrastructure for enabling data to discovery for the life sciences. PLOS Biol. 2016;14(1):e1002342.

85. Anders S, Pyl PT, Huber W. HTSeq - a Python framework to work with high-throughput sequencing data. Bioinformatics. 2015;31(2):166-169.

86. Chougule KM, et al. Improved RNA-seq workflows using CyVerse cyberinfrastructure. Curr Protoc Bioinformatics. 2018;63(1):e53.

87. Yates AD, et al. Ensembl 2020. Nucleic Acids Res. 2019;48(D1):D682-D688.

88. Reich M, Liefeld T, Gould J, Lerner J, Tamayo P, Mesirov JP. GenePattern 2.0. Nat Genet. 2006;38(5):500-501.

89. Love MI, Huber W, Anders S. Moderated estimation of fold change and dispersion for RNA-seq data with DESeq2. Genome Biol. 2014;15(12):550.

90. Bult CJ, Blake JA, Smith CL, Kadin JA, Richardson JE, Mouse Genome Database Group. Mouse Genome Database (MGD) 2019. Nucleic Acids Res. 2019;47(D1):D801-D806.

91. Subramanian A, et al. Gene set enrichment analysis: a knowledge-based approach for interpreting genome-wide expression profiles. Proc Natl Acad Sci U S A. 2005;102(43):15545-15550.

92. Mootha VK, et al. PGC-1alpha-responsive genes involved in oxidative phosphorylation are coordinately downregulated in human diabetes. Nat Genet. 2003;34(3):267-273.
93. Liberzon A, et al. Molecular signatures database (MSigDB) 3.0. Bioinformatics. 2011;27(12):1739-1740.

94. Liberzon A, et al. The molecular signatures database hallmark gene set collection. Cell Syst. 2015;1(6):417-425.

95. Shannon P, et al. Cytoscape: a software environment for integrated models of biomolecular interaction networks. Genome Res. 2003;13(11):2498-2504.

96. Merico D, Isserlin R, Stueker O, Emili A, Bader GD. Enrichment Map: a network-based method for gene-set enrichment visualization and interpretation. PLoS One. 2010;5(11):e13984.

97. Kucera M, Isserlin R, Arkhangorodsky A, Bader GD. AutoAnnotate: a Cytoscape app for summarizing networks with semantic annotations. F1000Research. 2016;5:1717.

98. Broad Institute. Morpheus. https://software.broadinstitute.org/morpheus. Accessed September $24,2020$.

99. Aroor AR, et al. Uric acid promotes vascular stiffness, maladaptive inflammatory responses and proteinuria in western diet fed mice. Metabolism. 2017;74(4):32-40.

100.Radu M, Chernoff J. An in vivo assay to test blood vessel permeability. J Vis Exp. 2013;(73):e50062.

101. Marsolais D, et al. Local not systemic modulation of dendritic cell S1P receptors in lung blunts virus-specific immune responses to influenza. Mol Pharmacol. 2008;74(3):896-903.

102. Mantel N. Evaluation of survival data and two new rank order statistics arising in its consideration. Cancer Chemother Rep. 1966;50(3):163-170. 